\title{
The Monetary Transmission Mechanism in the Tropics A Narrative Approach
}




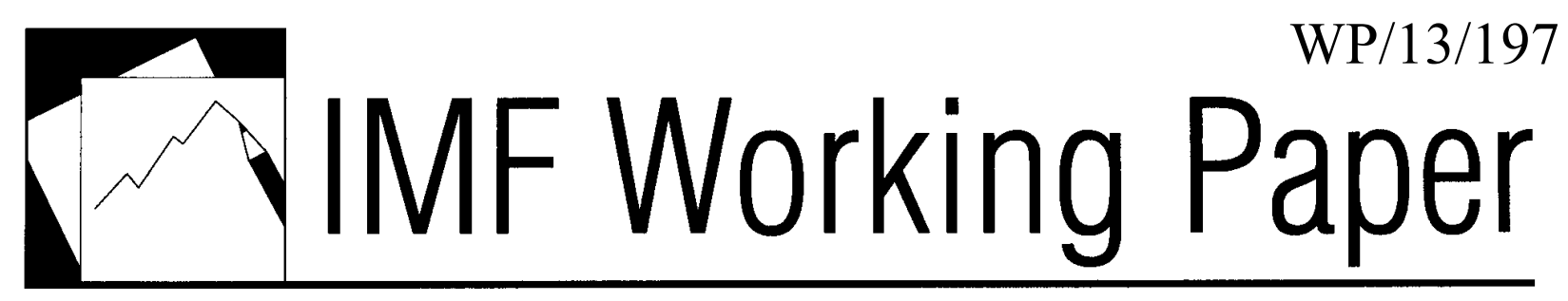

The Monetary Transmission Mechanism in the Tropics: A Narrative Approach

Andrew Berg, Luisa Charry, Rafael Portillo and Jan Vlcek* 


\title{
IMF Working Paper
}

\author{
Research Department
}

\begin{abstract}
The Monetary Transmission Mechanism in the Tropics: A Narrative Approach Prepared by Andrew Berg, Luisa Charry, Rafael Portillo and Jan Vlcek*
\end{abstract}

Authorized for distribution by Andrew Berg and Catherine Pattillo

September 2013

\section{This Working Paper should not be reported as representing the views of the IMF. The views expressed in this Working Paper are those of the author(s) and do not necessarily represent those of the IMF, IMF policy or DFID. Working Papers describe research in progress by the author(s) and are published to elicit comments and to further debate.}

\begin{abstract}
Many central banks in low-income countries in Sub-Saharan Africa are modernising their monetary policy frameworks. Standard statistical procedures have had limited success in identifying the channels of monetary transmission in such countries. Here we take a narrative approach, following Romer and Romer (1989), and center on a significant tightening of monetary policy that took place in 2011 in four members of the East African Community: Kenya, Uganda, Tanzania and Rwanda. We find clear evidence of the transmission mechanism in most of the countries, and argue that deviations can be explained by differences in the policy regime in place.

JEL Classification Numbers: E42, E E44, E52, E58

Keywords: Monetary Transmission Mechanisms, Low Income Countries

Author's E-Mail Address:aberg@imf.org; lcharry@imf.org; rportillo@imf.org; janvlcekatcz@gmail.com

${ }^{*}$ The International Monetary Fund and OGResearch. This working paper is part of a research project on macroeconomic policy in low-income countries supported by the U.K.'s Department for International Development. The project draws in part on earlier work with IMF colleagues, particularly Rogelio Morales. We would also like to thank Steve O'Connell and seminar participants at the IMF's African Department and the Center for the Study of African Economies in Oxford. All errors remain ours.
\end{abstract}




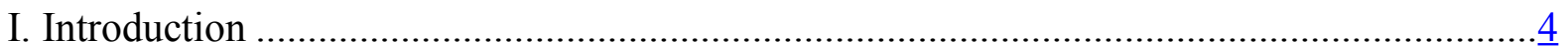

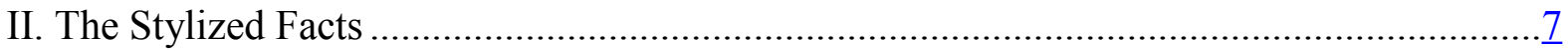

A. Structure of the Economy and the Financial Sector.................................................

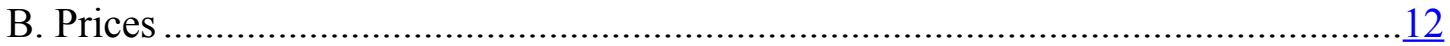

C. Policy Regimes............................................................................................13

Box 1. EAC4 - Exchange Rate Arrangements and the Capital Account …….. 18

Box 2. EAC4 - Monetary Policy Frameworks ……………………………......20

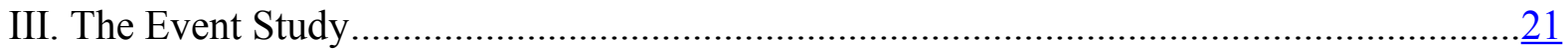

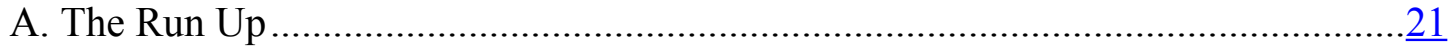

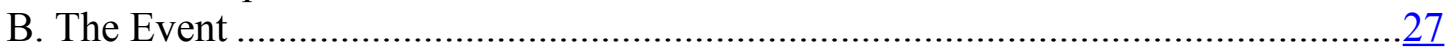

Box 3. An Overview of the Transmission Mechanisms of Monetary Policy ..29

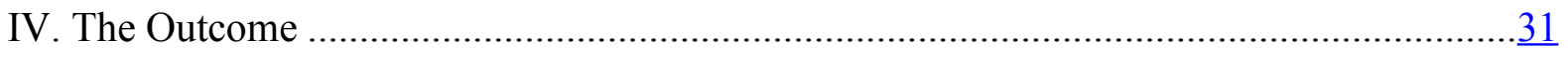

V. On The Role of Global Risk Appetite and Supply Shocks .................................................42

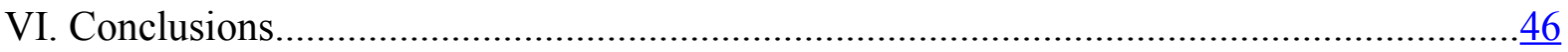

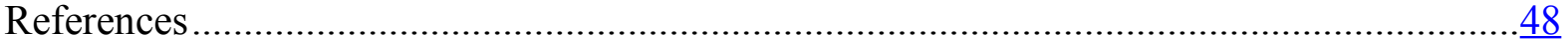

Tables

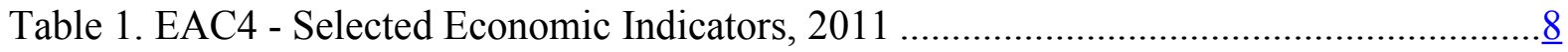

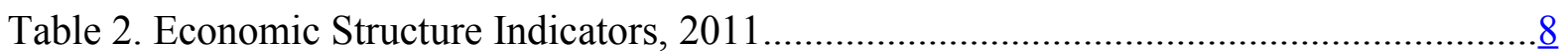

Table 3. Selected Financial Sector Indicators, 2011 .........................................................11

Table 4. EAC4 - Summary of Policy Regimes ....................................................................

Table 5. EAC4 - Monetary Policy Mandates and Instruments ...............................................19

Table 6. EAC4 - Monetary Policy Transmission Channels ...................................................

\section{Figures}

Figure 1. EAC4 - Financial Depth Indicators ....................................................................

Figure 2. EAC4 - Inflation (YoY, Percent) .....................................................................

Figure 3. EAC4 - Interbank Rates (Percent) ……………..............................................

Figure 4. Uganda - Selected Interest Rates (Percent) ..........................................................

Figure 5. World Commodity Prices (Index, Jan=100).......................................................22

Figure 6. EAC4 - Selected Economic Indicators (Part I) ....................................................23

Figure 7. Kenya - Selected Interest Rates (Percent) …………………..............................

Figure 8. Tanzania - Real Money Growth and Short-Term Interest Rates, .............................26

Figure 9. Rwanda - Real Money Growth and Short-Term Interest Rates ..............................27

Figure 10. A Basic Diagram of the Monetary Transmission Mechanism ................................

Figure 11. EAC4 - Selected Economic Indicators (Part II) …………………………............. 
Figure 12. EAC4 - Money Market Interest Rates (Percent) ............................................. $\underline{33}$

Figure 13. EAC4 - Banking Interest Rates (Percent) ..........................................................34

Figure 14. EAC4 - Real Interest Rates and the Output Gap (Percent) ................................. 35

Figure 15. EAC4 - Real Import Growth (YoY, Percent) ............................................... 36

Figure 16. EAC4 - Non-Food Inflation and the Output Gap (Percent) ................................. 37

Figure 17. EAC4 - Interest Rates (Percent) and Exchange Rates .........................................38

Figure 18. EAC4 - Headline Inflation and Exchange Rate Change (YoY, Percent) ............... 39

Figure 19. EAC4 - Interest Rates and Credit Growth (Percent) .......................................... 40

Figure 20. EAC4 - Excess Reserves (Percent of Required Reserves) .................................. 42

Figure 21. Emerging and Frontier Markets Exchange Rates, (Index) .................................. 43

Figure 22. VIX (Index) and EAC4 Exchange Rates.....................................................44

Figure 23. EAC4 - Headline and Core Inflation (YoY, Percent)......................................... 46 
Skillful exploitation of natural experiments that provide identifying variation in important variables represents the best hope for increasing our empirical understanding of macroeconomic fluctuations. While lacking the scientific pretension of an explicit probability model, careful historical discussions of events surrounding particular monetary changes, such as those provided by Friedman and Schwartz (1963), persuade precisely because they succeed in identifying relevant natural experiments, and describing their consequences. (Summers, 1991, p. 130)

\section{INTRODUCTION}

Macroeconomic outcomes in many Low-Income Countries (LICs) in Sub-Sahara have greatly improved in recent years. Many central banks in the region are now looking to modernize their frameworks to make policy more forward-looking, to further promote macroeconomic stability and ultimately growth and financial development. At the same time, uncertainty about how to proceed abounds. At the heart of this uncertainty is the question of how different LICs are in ways that matter for monetary policy. How does monetary policy transmit to the economy?

The challenges to identifying the transmission mechanism in the data are big anywhere and probably larger in LICs. Studies on the effects of monetary policy in activity and prices in LICs have largely relied on the use of statistical techniques such as VARs, SVAR, VECMs, and single-equation estimation, and often find weak or insignificant effects of monetary policy. ${ }^{1}$ As elsewhere, policy is endogenous to events in the economy. More than elsewhere, the structure of the economy itself is evolving, for example as the financial system develops. Meanwhile, the transmission of policy itself depends on the policy framework, which is sometimes both obscure and changing. Finally, large supply shocks are frequent and data noisy and scarce. Thus, analysis based on VARs - which require relatively long times series with consistent policy frameworks - is likely to be unfruitful. Even simple "stylized facts" based on large panels of countries may mislead by confounding the effects of different sorts of shocks.

\footnotetext{
${ }^{1}$ An influential statement of the proposition that the transmission mechanism is weak and unreliable, and that this has important policy implications, can be found in Mishra, Montiel and Spilimbergo (2012). For reviews of the literature see IMF (2008), Mishra and Montiel (2012), and Davoodi, Dixit and Pinter (2013) for the East African Community.
} 
In this paper, we apply what Romer and Romer (1989) call the "narrative approach" to identifying the effects of monetary policy: "The central element of this approach is the identification of monetary shocks through non-statistical procedures... The method involves using the historical record... to identify episodes when there were large shifts in monetary policy or in the behavior of monetary policy that were not driven by developments on the real side of the economy." As Summers (1991) and Romer and Romer (1989) argue, views on the real effects of monetary policy in the United States have been more influenced by the narrative arguments of Friedman and Schwartz (1963) and by reference to the real effects of the "Volcker disinflation", than by formal statistical analysis.

Our narrative centers on a significant tightening of monetary policy that took place in late 2011 in three country members of the East African Community: Kenya, Uganda, and Tanzania, as well as the somewhat different experience of a fourth EAC country, Rwanda. Central bank Governors from the EAC4 met together in October 2011 and decided that strong monetary policy action was needed to stem high and rising inflation, even at a cost to output, and they immediately acted. This paper uses this event to understand some of the basic facts of the transmission mechanism in low-income countries. To the best of our knowledge, this is the first attempt to apply this methodology to low-income countries. ${ }^{3}$ The clean-cut nature of the event allows us to consider it a "natural experiment" from which significant inferences can be drawn.

Of course, nowhere do monetary policy authorities act in an economic vacuum, and it is difficult if not impossible to find monetary policy responses that were completely unrelated to developments in the real economy. In the case of East Africa, the event we study took place in the context of sizeable commodity price shocks. Since 2003, two significant increases in world food and energy prices have been recorded. The first surge took place just prior to the world financial crisis, with food prices soaring by 44 percent at their peak in 2008Q1. This resulted in substantial inflationary pressures in the EAC4. A sharp decline of commodity and food price in $2008 \mathrm{H} 2$ gradually moderated inflation in 2009 , even as monetary policies remained accommodative in all EAC4's countries.

In 2010-2011 a second major commodity price shock hit and inflation again took off in the EAC4. Monetary policies remained fairly loose in Kenya, Uganda, and Tanzania, with only cautious and ineffective efforts to tighten, perhaps encouraged by the experience of gradually moderating inflation without policy tightening in $2009 .{ }^{4}$ The commodity price shocks turned

\footnotetext{
${ }^{2}$ Romer and Romer (1989), pp. 1.

${ }^{3}$ We are aware of almost no papers that apply narrative identification to the analysis of monetary policy transmission outside the United States, let alone in low-income countries. Kim (1999) conducts an event study of the monetary contraction in December 1999 in Korea, but clearly this tightening was in response to the coincident financial crisis. Huang and Shen (2001) use a narrative approach to examine the reaction function in Taiwan. A number of papers examine fiscal policy natural experiments, again mainly in the United States or at most other developed economies, as in Cummins et al. (1994) and Romer and Romer (2010).

${ }^{4}$ This is suggested with respect to Kenya in IMF (2011).
} 
out to be much more persistent this time, and they combined with vigorous economic activity, a negative balance of payments shock and accommodative policy to further accelerate inflation and de-anchor expectations, weakening the exchange rate in an inflationary spiral. In Rwanda, in contrast, tighter monetary policy and a stable exchange rate kept inflation from taking off.

In the face of these events, the governors of the EAC4 central banks agreed at the October 2011 meeting that policy needed to be tightened significantly in order to bring inflation under control. This tightening represents the event we examine here.

While the tightening took place in response to economic events, this does not make it endogenous and thus invalidate our narrative approach to identifying the monetary transmission mechanism. Throughout 2011, concerns increased about the adequacy of the policy stance. However, it was unclear when a tightening might come or how strong it would be. Indeed, the narrative suggests that some observers were becoming concerned that it might not come at all. Thus, when it came it was at least partly unexpected, unusual in the language of Friedman and Schwartz (1963). We can thus ask, what did this large monetary policy tightening shock do?

The event study suggests that the transmission mechanism in these economies is alive and well: after a large policy-induced rise in the short-term interest rate, lending and other interest rates rise, the exchange rate tends to appreciate, output tends to fall, and inflation declines. In particular, we find the clearest transmission in Uganda, where the Inflation Targeting (IT) lite regime itself is simpler and more transparent. In Kenya transmission was effective once the authorities explicitly signaled the monetary policy stance with a short-term interest rate and described their intentions in terms of their inflation objective. In regimes where the stance of monetary policy is harder to asses such as Tanzania, which conducts monetary policy under a de jure monetary targeting regime and Rwanda, a de facto exchange rate peg, the transmission of monetary policy to lending interest rates is less evident. Nonetheless, in Tanzania the exchange rate seems to respond strongly to adjustments of the monetary policy stance.

The multiplicity of policy instruments (and potential conflicts among them) used in some cases may have made it harder to discern the stance of policy. In Tanzania, where both money and interest rates served as policy instruments, volatile short-term rates did not translate as clearly into movements in lending rates. In Rwanda, substantial exchange rate intervention, along with tighter monetary policy, may have mitigated some of the negative effects the food price shocks may have had on inflationary expectations in the other countries.

The (limited) literature on monetary policy transmission in LICs has naturally emphasized the importance of structural features of the economies, particularly the nature of the financial system. We see mixed signs of the importance of financial development. All four countries, like other LICs, have relatively small, concentrated, and bank-dependent financial systems, to varying degrees. In particular, Kenya's large financial sector makes it an outlier. However, the variation across countries in the transmission mechanism does not seem tightly linked to 
the degree of financial development. Kenya has one of the clearest transmissions, but so does Uganda, whose financial sector does not stand out.

The nature of the policy regime, on the other hand, appears critical to the nature of transmission. In Kenya, relatively high degrees of financial development did not translate into effective transmission until the policy regime was reformed to emphasize the smoothing of - and signaling role of - short-term interest rates. In Rwanda, heavy management of the exchange rate weakened the exchange rate channel. At the same time, the illiquid and underdeveloped interbank market made it harder to infer the stance of policy from interest rates and may have weakened the interest rate transmission mechanism. Meanwhile the experience of Uganda and Kenya, in turn, suggests that reforms to the policy regime may allow rapid changes in the interbank market.

The paper proceeds as follows: We first present the stylized facts of the countries under study, including the fundamental characteristics of the structure of the economy, the financial system, prices and the policy regimes. We then proceed to the event study, identifying the policy shock and tracing out the effects of these shocks on the main macroeconomic variables: interest rates, credit aggregates, the exchange rate, output, and inflation. By analyzing a few cases in a few countries at similar times, we are able to tease out some of the differences policy frameworks and economic structure may make, and to help isolate the effects of policy. Finally, we draw some lessons.

\section{The STYLIZED FACTS}

\section{A. Structure of the Economy and the Financial Sector}

The four countries of interest here are representative Sub-Saharan Africa (SSA) LICs. This means that each has a rich and unique history. Kenya, the largest of the four, is remarkable for its steady, moderate, growth over the past few decades and its relatively developed economy. The other three reflect the common pattern of dramatic political and economic turmoil from the 1970s through the 1990s, with thoroughgoing socialism (Tanzania) and civil war (Uganda and Rwanda). All four are among SSA's many "success stories" since the mid1990s, with the achievement of macroeconomic and political stability and rapid economic growth (Table 1). All but Kenya benefited from multilateral debt relief initiative in the last decade and all four have sustainable levels of external and domestic debt. ${ }^{5}$

\footnotetext{
${ }^{5}$ For broader perspectives see Nord et al. (2009), Selassie (2008) and recent Article IV reports on each country.
} 
Table 1. EAC4 - Selected Economic Indicators, 2011

\begin{tabular}{l|c|c|c|c}
\hline Country & $\begin{array}{c}\text { Nominal GDP } \\
\text { (USD Billions) }\end{array}$ & $\begin{array}{c}\text { Population } \\
\text { (Millions) }\end{array}$ & $\begin{array}{c}\text { Real GDP Per } \\
\text { Capita } \\
\text { (USD, PPP) }\end{array}$ & $\begin{array}{c}\text { Average Real GDP } \\
\text { Growth } \\
\text { (Percent, 2001-2011) }\end{array}$ \\
\hline Kenya & 34 & 42 & 476 & 4.2 \\
Uganda & 17 & 35 & 374 & 7.3 \\
Tanzania & 24 & 46 & 460 & 6.9 \\
Rwanda & 6 & 11 & 360 & 7.9 \\
\hline
\end{tabular}

Source: IMF, World Bank.

All four are part of the East African Community (EAC), which was established in 2000 to promote political, economic and social cooperation and now consists of a customs union (2005) and a common market (2010). Work to consolidate a monetary union is underway. We thus refer to them as the EAC4. ${ }^{6}$

The economic structure of the EAC4 is also broadly characteristic of SSA LICs: low trade shares, mostly commodity exports (coffee, tea and other agricultural produce, metals and minerals, and recently oil and gas (Uganda and Tanzania)), high though falling aid dependence, service-sector-led growth, and a large agricultural sector and rural population. The terms of trade have been fairly stable or rising in recent years (Table 2).

Table 2. Economic Structure Indicators, 2011

\begin{tabular}{lccccc}
\hline \multicolumn{1}{c}{ Groups } & $\begin{array}{c}\text { Exports } \\
\text { (\% of GDP) }\end{array}$ & $\begin{array}{c}\text { Imports } \\
\text { (\% of GDP) }\end{array}$ & $\begin{array}{c}\text { Aid } \\
\text { (\% of GDP) }\end{array}$ & $\begin{array}{c}\text { Rural } \\
\text { Population } \\
\text { (\% of Total) }\end{array}$ & $\begin{array}{c}\text { Commodity } \\
\text { Exports } \\
\text { (\% of Exports) 1/ }\end{array}$ \\
\hline Kenya & 29.1 & 46.0 & 9.8 & 76.0 & 60.9 \\
Uganda & 23.7 & 34.5 & 9.9 & 84.4 & 62.6 \\
Tanzania & 31.1 & 50.2 & 10.3 & 73.3 & 73.3 \\
Rwanda & 13.4 & 32.5 & 19.7 & 80.9 & 89.0 \\
\hline Average EAC4 & 24.3 & 40.8 & 12.4 & 78.6 & 71.4 \\
\hline Low Income Countries & 28.3 & 48.4 & 13.1 & 69.2 & 64.0 \\
Emerging Economies & 42.2 & 41.4 & 1.8 & 34.5 & 27.9 \\
Advanced Economies & 65.5 & 61.0 & 0.0 & 20.5 & 19.5 \\
\hline
\end{tabular}

$1 /$ Includes exports of food, agricultural raw materials and ore and minerals. Data for Kenya is for 2010. Source: IMF estimates, World Bank, OECD.

Financial systems also share some of the characteristics of SSA LICs, with small and concentrated private-bank-dominated financial systems, a large informal financial sector, shallow capital markets (except Kenya), short yield curves (except Kenya and more recently

\footnotetext{
${ }^{6}$ The EAC also includes Burundi, which we exclude here to focus the paper and on the grounds that it is a "fragile state" according to the standard World Bank classification.
} 
Uganda), and substantially dollarization (Table 3 ). ${ }^{7}$ In all four countries, commercial banks maintain substantial excess reserve deposits at the central bank. These features reflect the general level of economic development, weak associated institutions such as credit bureaus and legal systems, a historical legacy of macroeconomic instability, and - as we will discuss - monetary policy regimes. ${ }^{8}$ All these features are often said to impair or even destroy the monetary policy transmission mechanism, creating some uncertainty with respect to the outcome of the monetary policy shock we analyze below. ${ }^{9}$

Also common in other SSA LICs is the rapid pace of financial development in the EAC4. In recent years, for example, the share of private credit to GDP has growth rapidly in all four countries, as has the share of the population that access financial services (Figure 1).

\footnotetext{
${ }^{7}$ Public debt markets offer short and long-term maturities in Kenya and Uganda, which introduced a primary dealer ranking system in 2004 that has increased secondary market liquidity. See Allen, Otchere and Senbet (2011).

${ }^{8}$ Access to credit tends to be limited by the low use and novelty of credit reference bureaus: Kenya has two such institutions, while Uganda, Tanzania (since 2010), and Rwanda (since 2012) have one each.

${ }^{9}$ On this point see Mishra, Montiel and Spilimbergo (2012). It is sometimes argued, specifically, that excess reserves imply that policy tightening is "pushing on a string" and is therefore ineffective (e.g. Saxegaard (2006)).
} 
Figure 1. EAC4 - Financial Depth Indicators

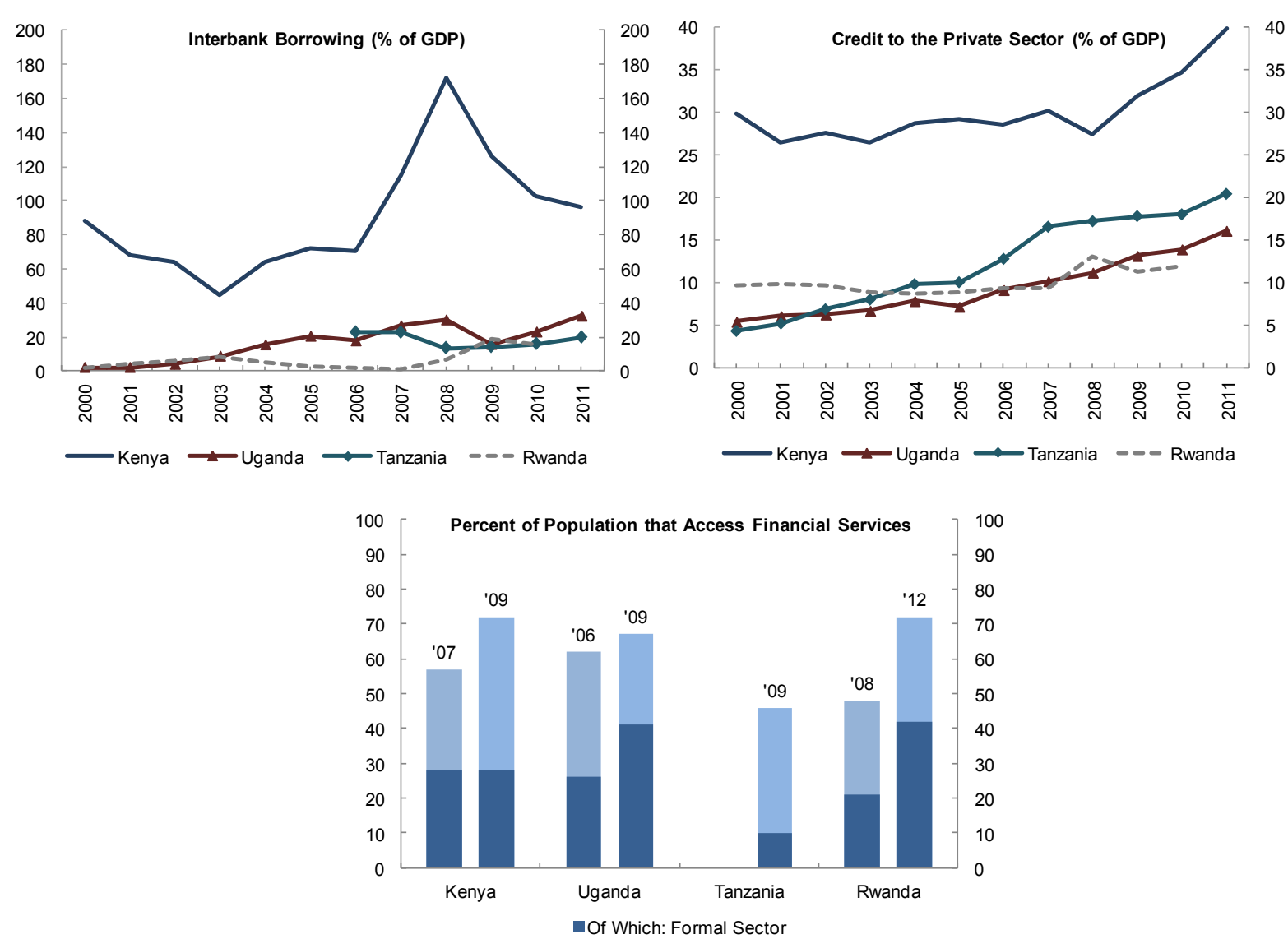

Source: National authorities, Finscope.

Additionally, the four economies exhibit different degrees of financial openness (based on an assessment of the de jure openness of the capital and financial accounts according to the Chinn-Ito index), with Uganda and Kenya being the more financially integrated of the four and Rwanda and Tanzania being the least (Table 3). Looking across the four countries, Kenya stands out for its relatively developed financial sector, with a larger and less concentrated banking system. With respect to other indicators, the other three countries look quite similar. With respect to overall financial access, differences in time, even over the past few years, are more important than the cross-country differences: Rwanda's financial access rates in 2012 being similar to Kenya's in $2009 .{ }^{10}$

\footnotetext{
${ }^{10}$ The Rwandan government has set targets for growth in credit (from private banks) to the private credit, as part of a program to foster financial deepening (see Government of Rwanda (2012)).
} 
Table 3. Selected Financial Sector Indicators, 2011

\begin{tabular}{|c|c|c|c|c|c|c|}
\hline Groups & $\begin{array}{l}\text { Credit to the Private } \\
\text { Sector } \\
\text { (Percent of GDP) }\end{array}$ & $\begin{array}{l}\text { Bank Credit to the } \\
\text { Private Sector } \\
\text { (Percent of GDP) }\end{array}$ & $\begin{array}{c}\text { 5-Bank Asset } \\
\text { Concentration } \\
\text { (Percent) 1/ }\end{array}$ & $\begin{array}{l}\text { Stocks Traded, } \\
\text { Total Value } \\
\text { (Percent of GDP) }\end{array}$ & $\begin{array}{c}\text { Dollarization } \\
2 /\end{array}$ & $\begin{array}{c}\text { Chinn-Ito } \\
\text { Financial } \\
\text { Openness Index } 3 /\end{array}$ \\
\hline Kenya & 38.1 & 33.6 & 60.5 & 2.6 & 10.8 & 1.1 \\
\hline Uganda & 17.9 & 13.8 & 73.6 & 0.1 & 21.8 & 2.5 \\
\hline Tanzania & 17.8 & 15.8 & 67.6 & 0.1 & 20.3 & -1.2 \\
\hline Rwanda & 16.9 & 13.2 & 100.0 & n.a. & 20.0 & -0.9 \\
\hline Average EAC4 & 22.7 & 19.1 & 75.4 & 0.9 & 18.2 & 0.4 \\
\hline Low Income & & & & & & \\
\hline $\begin{array}{l}\text { Countries } \\
\text { Emerging }\end{array}$ & 19.6 & 18.8 & 80.0 & 4.9 & 12.8 & -0.4 \\
\hline $\begin{array}{l}\text { Economies } \\
\text { Advanced }\end{array}$ & 60.9 & 49.1 & 69.6 & 26.6 & 4.0 & 0.3 \\
\hline Economies & 145.3 & 133.7 & 84.8 & 70.2 & 0.5 & 2.2 \\
\hline
\end{tabular}

$1 /$ Assets of five largest banks as a share of total commercial banking assets.

2/ Foreign currency deposits as a share of total deposits in the banking system.

$3 /$ Index values are for 2010 . The index takes a maximum value of 2.5 for the most financially open economies and a minimum of -1.9 for the least financially open. See Chinn and Ito (2008).

Source: IMF estimates, World Bank 


\section{B. Prices}

Inflation in the EAC4 is volatile and highly correlated across countries, suggesting the existence of underlying common causes. Inflation has frequently soared to double-digit levels, despite the common EAC goal to contain inflation to below 5 percent (Figure 2). The high volatility of inflation is mostly explained by the high share of food items in the overall $\mathrm{CPI}$, in line with the economic structure of member countries. The weight of food prices in the CPI is highest in Tanzania (47 percent), followed by Kenya (36 percent), Rwanda (35 percent) and Uganda (27 percent). ${ }^{11}$

Domestic food crops yields in the region are highly dependent on weather patterns, which are characterized by a bimodal annual rainfall cycle. The existence of trade barriers to protect the domestic agricultural production has increased the sensitivity of the domestic food supply to unfavorable weather conditions. Some government policies have been implemented to moderate the effect of adverse domestic weather conditions in the food supply, including the promotion of storable crops (such as cereals) and the establishment of centralized marketing arrangements. ${ }^{12}$

For our purposes, a critical feature of these countries is the complexity and dynamism of their monetary policy and exchange rate frameworks, and correspondingly of their money market and other short-term interest rate markets. We examine this in the next section.

\footnotetext{
${ }^{11}$ The Tanzania CPI survey includes rural households, unlike the surveys in Kenya, Uganda and Rwanda.

${ }^{12}$ See Murgasova, Gorbanyov, Saenz \& Sobolev (2008).
} 
Figure 2. EAC4 - Inflation (YoY, Percent)
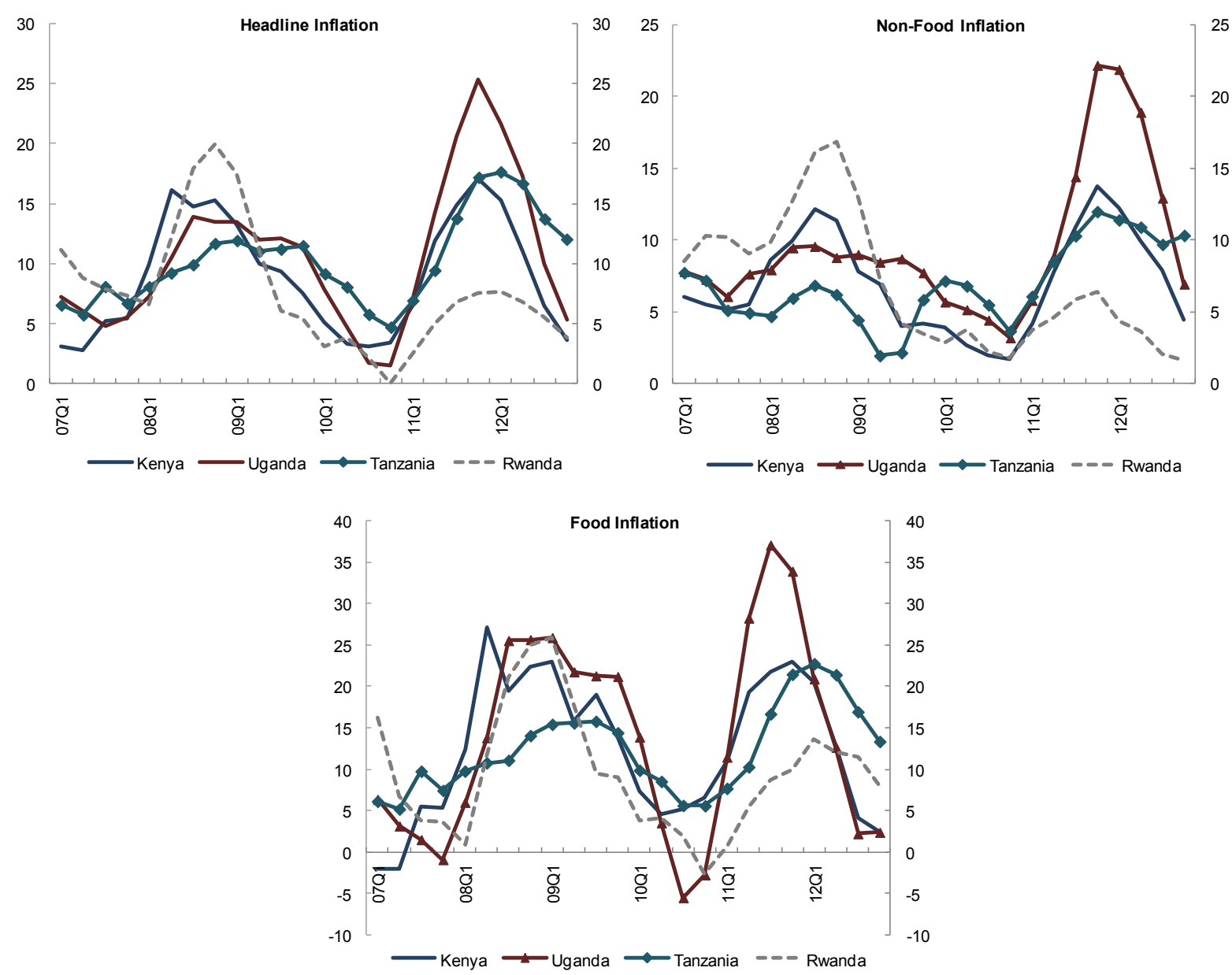

Source: National authorities

\section{Policy Regimes}

Monetary and exchange rate regimes in the EAC4 can in general be characterized as hybrid regimes, under which several instruments are used to target multiple policy objectives, combining elements of different policy frameworks (such as inflation targeting and monetary targeting). Different degrees of exchange rate management are also present. 


\section{Table 4. EAC4 - Summary of Policy Regimes}

\begin{tabular}{c|c|c}
\hline Country & $\begin{array}{c}\text { Exchange Rate } \\
\text { Arrangement }^{13}\end{array}$ & Monetary Policy Framework \\
\hline Kenya & Free floating & Flexible monetary targeting \\
Uganda & Floating & Inflation targeting lite \\
Tanzania & Floating & Monetary targeting \\
Rwanda & Crawl-like arrangement & Flexible monetary targeting \\
\hline
\end{tabular}

Source: IMF estimates.

Central banks intervene to manage the exchange rate, though to varying degrees. The authorities generally state that interventions are aimed only at smoothing fluctuations and building up foreign currency buffers. Other concerns may at times be involved, including that rapid nominal depreciation will cause inflation or increase dollarization and a desire to maintain a competitive real exchange rate. ${ }^{15}$

Reflecting the hybrid nature of these regimes, it is tricky to characterize the frameworks for the conduct of monetary policy in the EAC4. As in most sub-Saharan African countries with managed floats, the central banks of Rwanda (NBR), Tanzania (BOT), and Kenya (and Uganda until July 2011) conduct monetary policy under a de jure monetary aggregate targeting framework, in principle adjusting the money supply to achieve intermediate targets in terms of broad money growth. However, these three regimes are much more flexible in practice.

The broader experience with such de jure money targeting regimes is that target misses are frequent, and at least in relatively low-inflation environments such misses are not associated with misses of inflation objectives. Rather, central banks tend to make judgments on an ongoing basis as to whether targets should be achieved, and if not how they should be revised for the next quarter, depending on outcomes in money and exchange rate markets and a broader sense of whether inflation and output (and other) objectives are being achieved. This is for various reasons, not least because to adhere to the targets would generate excessive volatility of short-term interest rates in the face of money demand shocks. This makes the stance of policy hard to grasp. ${ }^{16}$

In the case of the EAC4, Tanzania adheres most closely to its de jure money targeting regime. Rwanda also tends to pay substantial attention to money aggregates, though its close control of the nominal exchange rate may create some tensions in practice. Kenya has over time paid less and less attention to monetary aggregates, culminating in September 2011 with

${ }^{13}$ According to the IMF's Annual report on Exchange Arrangements and Exchange Restrictions (2012).

${ }^{14}$ Since December 2011, the Tanzanian Shilling has been trading within a 2 percentage point range against the U.S. dollar. See IMF (2013).

${ }^{15}$ See Adam (2012) and Masson and Pattillo (2005).

${ }^{16}$ See IMF (2008), Adam, Maturu, Ndung'u and O'Connell (2010), Berg, Portillo and Unsal (2010), and Kasenkende and Brownbrige (2011) for discussions of this issue. 
a clear announcement of a move to use the short-term interest rate as its main policy instrument, with the objective of achieving its inflation objectives (see Andrle et al. 2013). Uganda too has undergone an important evolution in this regard, moving from quite strict money targeting until October 2009 to explicit use of short-term interest rates in pursuit of its inflation objectives (inflation targeting lite, see Box 2).

To varying degrees, interbank interest rates have been volatile as a result of more-or-less strict adherence to announced money growth targets in the face of shocks to money demand. This is clearest in Tanzania, reflecting its tighter adherence to announced money growth targets, and in Uganda prior to its move away from strict money targeting in October 2009. It is least in Uganda after the switch and in Kenya, consistent with its flexible adherence to monetary targets has been quite flexible in recent years (Figure 3 ). ${ }^{17}$

Beyond volatility of short-term market rates, in such hybrid regimes it is often difficult to know how to interpret any particular interest rate. Sometimes "policy rates" are not market clearing, present no arbitrage opportunities with other short-term interest rates, and contain no signal of policy intention. But this can change suddenly as the details of central bank operations change. In general, we use the interbank rate and sometimes the treasury bill rate as an indicator of the market short-term interest rate, with due reference to "policy rates" as appropriate.

\footnotetext{
${ }^{17}$ Rwanda's relatively smooth interbank interest rates reflect a shallow interbank market and lower adherence to money targets.
} 
Figure 3. EAC4 - Interbank Rates (Percent) ${ }^{18}$
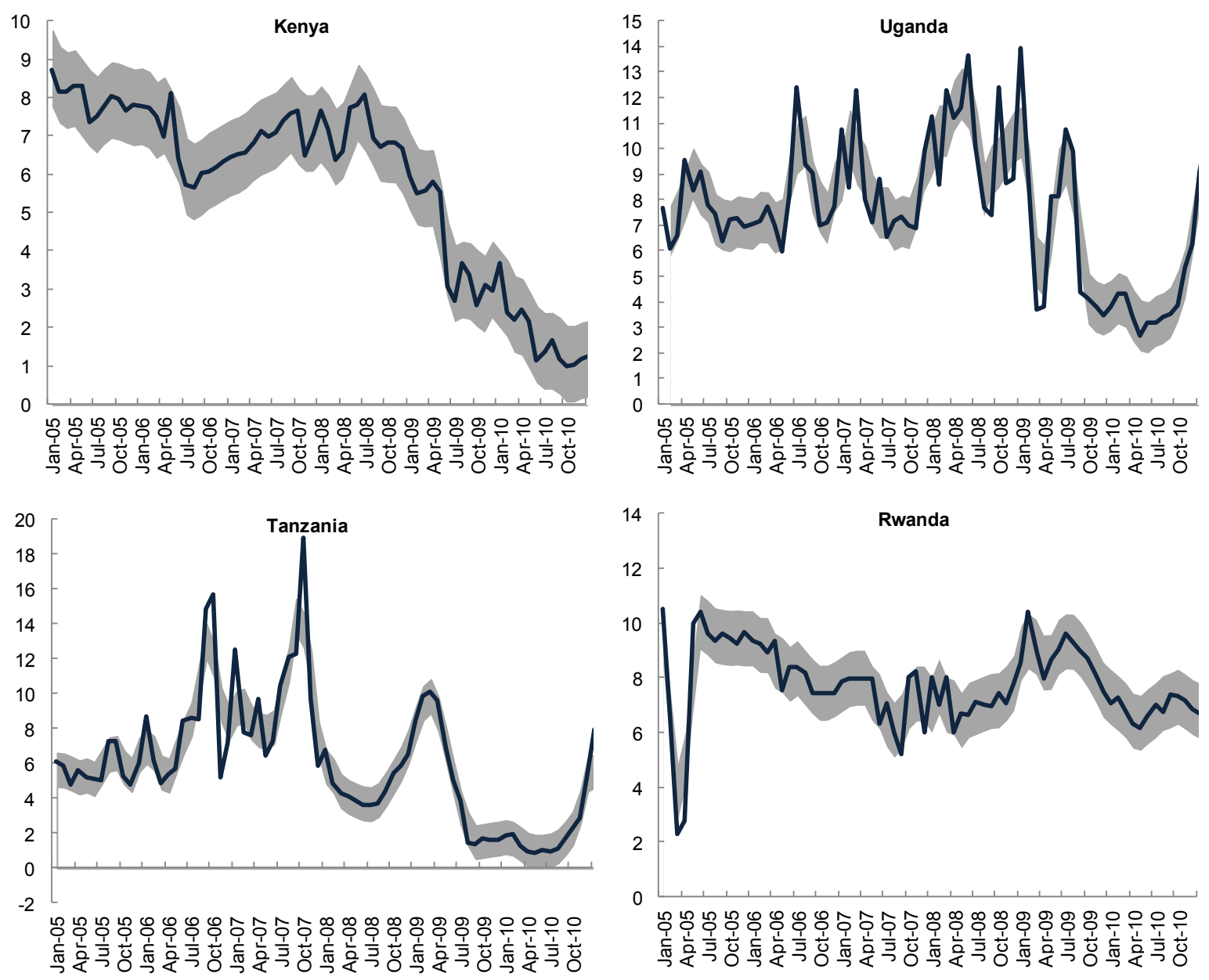

Source: IMF estimates, National authorities

The recent evolution of Uganda's monetary policy regime is illustrative of the general point that the transmission mechanism depends on the policy framework itself and on the operational procedures of monetary policy implementation. Prior to October 2009, the Bank of Uganda (BOU) adhered closely to its money targets. Shocks to money demand thus generated substantial movements in interbank rates that did not signal policy intentions and which were often temporary and, as a result, had little effect on lending rates or other aspects of the transmission mechanism (Figure 4). Since October 2009 the BOU has allowed for more flexibility in daily money market operations in order to smooth short-term money market rates. This immediately reduced the volatility of interbank rates. In July 2011 the BOU officially launched the IT-lite regime described in Box 2 and introduced the Central Bank Rate (CBR) to target the interbank rate. These changes to the policy framework and operations set the stage for changes in short-term interest rates (specifically the CBR) to have a larger impact on the economy.

${ }^{18}$ Shaded regions correspond to plus/minus $1 \%$ bands around 9-month centered moving averages. 
Figure 4. Uganda - Selected Interest Rates (Percent)

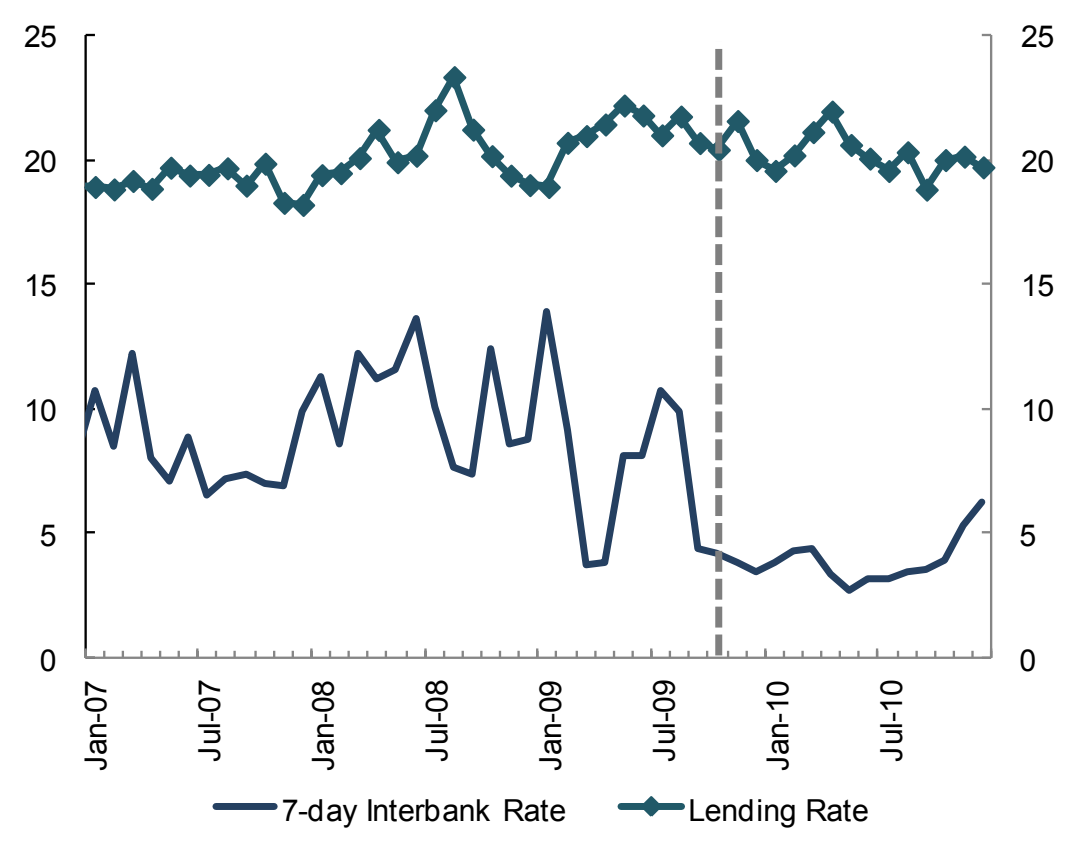

Source: Bank of Uganda

The degree of central bank independence varies across the four countries. The Central Bank Acts of the members of the EAC4 were modernized during the past decade. On a de jure basis, the BOT and the NBR are the most independent of the four, as Government involvement is limited to consultations with the monetary authority, whereas in Kenya and Uganda the Government has the potential to supersede policies adopted by the central banks if they are deemed inconsistent with their objectives. Even though the monetary policy mandates in the four countries are ample and complex (see Table 5), the overriding policy objective is price stability and all central banks have made explicit commitments to an inflation goal and have set a common inflation target of 5 percent. 


\section{Box 1. EAC4 - Exchange Rate Arrangements and the Capital Account}

According to the Annual Report on Exchange Arrangements and Exchange Restrictions (IMF, 2011), the exchange rate arrangement of Kenya is classified as free floating, and official foreign exchange market interventions by the Central Bank of Kenya (CBK) are conducted to moderate the rate of change of the exchange rate, either through auctions (the average rate is published after the auction closes) or through direct interventions in the dealing system, under which the market is informed but amounts and rates are not published. Additionally, the capital account is open and, given the size and nature of the capital flows, Kenya has been classified as a Frontier Market. ${ }^{19}$

Uganda is classified as a floating regime, and the authorities intervene in the foreign exchange market in order to maintain stability in the foreign exchange market. Since 2010, the Bank of Uganda (BOU) has been conducting daily purchases for reserve buildup purposes, while engaging in targeted sales occasionally as deemed necessary. The BOU publishes information on its interventions in its monthly, quarterly and annual reports, including the amounts purchased or sold through the reserve buildup program and through targeted transactions. There are no capital controls.

Tanzania's exchange rate arrangement was officially classified as a floating regime through the period under consideration. However, unlike the cases of Kenya and Uganda, the Bank of Tanzania (BOT) is the predominant supplier of foreign exchange in a rather shallow market, as it seeks to sterilize liquidity generated by government spending financed by official inflows. Other objectives for intervention in the foreign exchange market include the smoothing of short-term exchange rate volatility and maintaining an adequate level of international reserves. The BOT announces the amount to be sold in the market through the dealing system on a monthly basis. Controls on capital account transactions are widespread and the capital account is de facto quite closed.

The exchange rate regime in Rwanda is classified as a crawl-like arrangement. The National Bank of Rwanda (NBR) sells foreign exchange directly to banks at their request at a price on the upper limit of the exchange rate corridor. The interbank market operates over the counter and data on the NBR's interventions in the foreign exchange market is not disclosed. Even though restrictions to capital account transactions are not prevalent, the absence of capital flows into the country is consistent with the view that the capital account is de facto closed.

\footnotetext{
${ }^{19}$ Frontier market is a term used to describe small and illiquid markets that are at an earlier stage of economic and financial development than emerging markets and that are expected to become one over time. The criteria for classification as a Frontier Market include the regulatory environment, degree of market accessibility and quality of the market infrastructure. Companies such as Standard \& Poor's, MSCI and FTSE compile investable indexes of Frontier Markets. Kenya is included in all three of them.
} 
Table 5. EAC4 - Monetary Policy Mandates and Instruments

\begin{tabular}{|c|c|c|}
\hline Country & Mandate & Instruments \\
\hline Kenya & $\begin{array}{l}\text { Price stability } \\
\text { Exchange rate stability } \\
\text { Financial stability } \\
\text { Support of Government policy }\end{array}$ & $\begin{array}{l}\text { Open market operations } \\
\text { Repo operations } \\
\text { FX intervention } \\
\text { Rediscount policy } \\
\text { Reserve requirements } \\
\text { Policy rate } \\
\text { Moral suasion }\end{array}$ \\
\hline Uganda & $\begin{array}{l}\text { Price stability } \\
\text { Financial stability }\end{array}$ & $\begin{array}{l}\text { Policy rate } \\
\text { FX intervention } \\
\text { Open market operations } \\
\text { Rediscount policy }\end{array}$ \\
\hline Tanzania & $\begin{array}{l}\text { Price stability } \\
\text { Financial stability } \\
\text { Support of Government policy }\end{array}$ & $\begin{array}{l}\text { Open market operations } \\
\text { Repo operations } \\
\text { Rediscount policy } \\
\text { Policy rate } \\
\text { FX intervention } \\
\text { Moral suasion }\end{array}$ \\
\hline Rwanda & $\begin{array}{l}\text { Price stability } \\
\text { Financial stability } \\
\text { Support of Government policy }\end{array}$ & $\begin{array}{l}\text { Open market operations } \\
\text { Rediscount policy } \\
\text { Reserve requirements } \\
\text { Policy rate } \\
\text { FX intervention }\end{array}$ \\
\hline
\end{tabular}

Source: National authorities, Christensen (2011) and Morales (2012). 


\section{Box 2. EAC4 - Monetary Policy Frameworks}

In Kenya, reserve money growth is the operating target, and growth in M2 and M3 are intermediate targets. Initially, the CBK sets the targets for a 6-months ahead period; since 2011 targets have been set for 3 and 6-months ahead periods. However, the monetary policy stance has been frequently adjusted without revising the targets. The CBK employs repo operations (repo and reverse repo), cash reserve requirements and rates on discount window operations as the key instruments managing the liquidity on the money market. The CBK also signals its monetary policy stance via the Central Bank Rate (CBR), which is reviewed and announced by the Monetary Policy Committee every month. In September 2011 the $\mathrm{CBK}$ clarified its operating procedures, emphasizing the CBR as the reference for overnight borrowing from its standing lending facility and for liquidity operations since November 2011. In 2012 the CBR was used mostly as a ceiling for repo auctions, with an increasing impact in guiding interbank rates.

In Tanzania the BOT's Monetary Policy Committee (MPC) sets -and Parliament approvesan operational target on reserve money and intermediate targets on the growth in M2 and M3. Annual broad money targets are set at the beginning of each fiscal and are revised in the middle of each fiscal year. Adherence to the targets is rather strict. Repo operations are the key instrument for managing liquidity on the money market, and the central bank is usually withdrawing liquidity from the system. The liquidity management effort is complemented by periodic adjustments in the pricing of standby facilities (the Discount facility and the Lombard facility). The bank also indicates the stance of policy through movements in the Bank Rate, which can potentially lead to inconsistent signaling with monetary targets.

In Rwanda, notwithstanding the heavily managed exchange rate, the NBR also sets reserve money as its operational target and a floor on net foreign assets as an intermediate target. The relatively closed capital account likely allows a certain degree of independence between exchange rate management and monetary policy. The MPC also decides on the level of the Key Repo Rate (KRR), which is the maximum rate for withdrawal and the minimum rate at which liquidity will be injected into the banking system for seven-day maturity operations. The monetary policy committee meets on a quarterly basis and on extraordinary occasions if deemed necessary. Liquidity surplus in the system is drained through open market operations.

In Uganda, the BOU announced a move from monetary targeting towards inflation targeting lite in July 2011. Under the new regime, an interest rate is the operating target of monetary policy (the Central Bank Rate (CBR)), which is set once a month and used to guide 7-day interbank interest rates. A corridor around the CBR is also defined to signal the allowed deviations from the interbank rate from the policy rate, and its width is frequently adjusted. The rediscount policy is also used often used by the BOU to signal policy. 
Finally, central banks are not necessarily immune to pressures from fiscal authorities that may influence monetary policy. ${ }^{20}$ Monetary financing of the Government's deficit is subject to defined limits in EAC4 countries (usually set as a percent of government revenues). Nonetheless, instances of exceptional financing still occur, particularly when market financing is considered expensive. More broadly, the prospect exists here, as elsewhere, that higher interest rates, by weakening the fiscal position, could bring government pressures to bear on the central bank. This risk is aggravated by the fact that the central banks are net debtors to the financial system, which means that interest rate increases can worsen the balance sheet of the central bank and could potentially require fiscal transfers from the government. $^{21}$

\section{ThE EVENT STUDY}

We broadly follow Romer and Romer (1989) and define a shock as episode in which a central bank undertakes overt and unusual actions to exert a contractionary influence on the economy in order to reduce inflation. Along these lines, we look closely at the narrative coming from the central banks in the region to find evidence that policy action was required to lower inflation.

The tightening in 2011Q4 followed a meeting of EAC Central Bank governors in October at which it was stated that inflation was getting out of control and that monetary policy needed to be tightened. ${ }^{22}$ This meeting and the resulting sharp policy actions represent the distinct monetary policy "shock" that allows us to trace the transmission mechanism. We now take a closer look at the tightening episode.

\section{A. The Run Up}

In the second half of 2010 international prices of food and energy shot up by more than 30 percent and 40 percent, respectively (Figure 5). Inflationary pressures in emerging and developing economies were expected to broaden in 2011 as output in most cases was back to pre-crisis levels, supported by accommodative macroeconomic policies, rising exports and capital inflows. Consequently, in the emerging and developing world policies needed to tighten to varying degrees. ${ }^{23}$

\footnotetext{
${ }^{20}$ Morales (2012) and Laurens (2005).

${ }^{21}$ This net debt position is the result of a history of sterilizing aid and FDI inflows, and of monetizing past government deficits. Aid inflows are high (ranging from 10 percent of GDP in Uganda and Kenya to 20 percent in Rwanda in 2011) and volatile.

${ }^{22}$ Bank of Tanzania (2011).

${ }^{23}$ IMF (2011a).
} 


\section{Figure 5. World Commodity Prices (Index, Jan=100)}

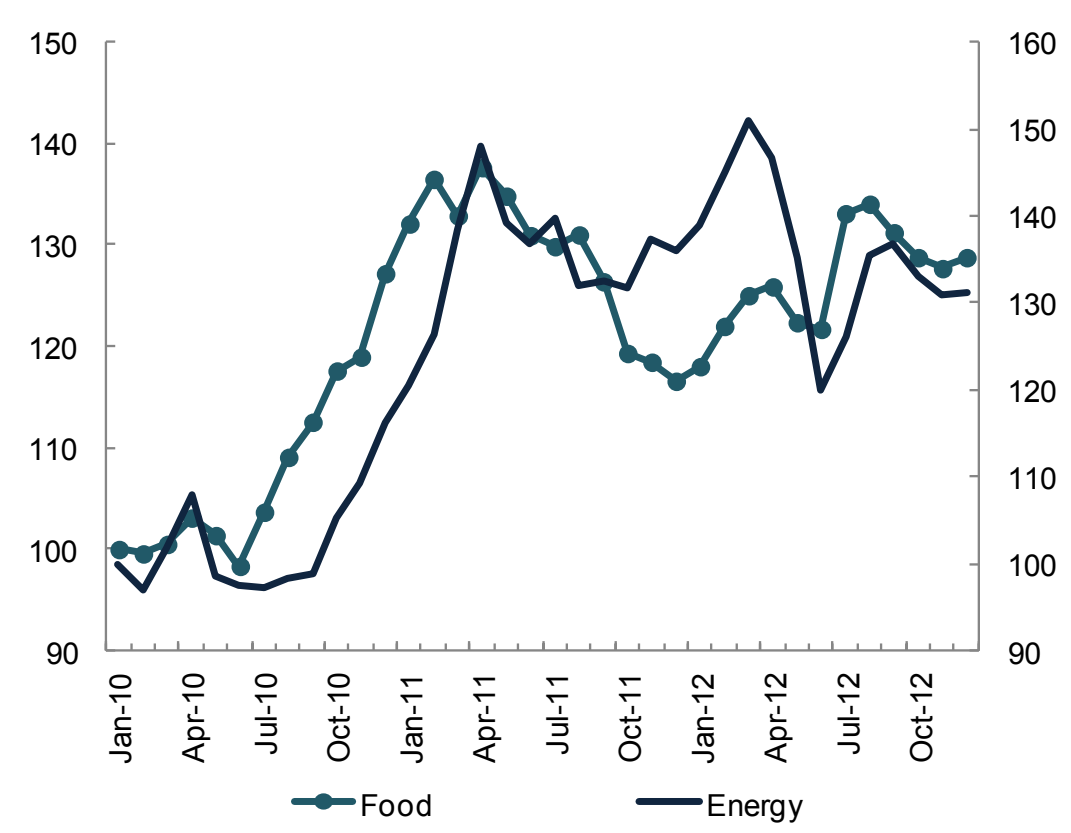

Source: IMF estimates.

The macroeconomic environment of the members of EAC4 during this conjuncture was similar, in many ways, to that of other emerging and developing economies: economic activity was recovering, supported by an accommodative policy stance. By 2011Q3 headline inflation in Kenya, Uganda and Tanzania had surpassed by far the common inflation target ( 5 percent). This reflected broadly similar factors in all three countries: the higher food and oil prices, domestic food price shocks, vigorous economic activity (with output well above trend in Kenya and Uganda) ${ }^{24}$, and pass-through from the exchange rate depreciation. To assess non-commodity inflationary pressures, we constructed an indicator of core inflation excluding food and fuel prices. ${ }^{25}$ We find that even though most of the increase in headline inflation during this period is indeed explained by the acceleration in food and fuel inflation, core inflation also increased substantially in all countries, almost doubling during the course of a year, and in all cases considerably overshooting the common inflation target. ${ }^{26}$ The

\footnotetext{
${ }^{24}$ Output gaps are estimated with a Hodrick-Prescott filter on the 4 quarter cumulative real GDP in Uganda and Tanzania and Non-Agricultural GDP in Kenya and Rwanda. The estimation sample includes data up to 2012Q3 to correct for end-of-sample bias. The analysis is available upon request.

${ }^{25}$ In Kenya, Tanzania, and Rwanda core inflation includes the following groups: Clothing and footwear, Furnishings, household equipment and routine household maintenance, Health, Education, Personal goods and services and Miscellaneous goods and services. In Uganda, core inflation includes: Clothing and footwear, Household and personal goods, Education, Health, entertainment and others. It should be noted that these measures are not necessarily the same as the ones compiled by local authorities.
}

${ }^{26}$ Moreover, the importance of food price inflation in driving overall inflation does not undermine the importance of monetary policy, see Section $\mathrm{V}$ for a discussion. 
vigorous activity, rising core inflation, and weak exchange rates are all consistent with evidence of accommodative monetary policies, with real interest rates strongly negative in all three countries (Figure 6). Also at times weighing on exchange rates were pressures on the capital account coming from swings in global risk aversion, which may have encouraged capital repatriation from the EAC. However, these pressures occurred in a context of growing imbalances and accommodative policies and seem to have compounded what was already a vulnerable situation (see Section V).

Figure 6. EAC4 - Selected Economic Indicators (Part I)

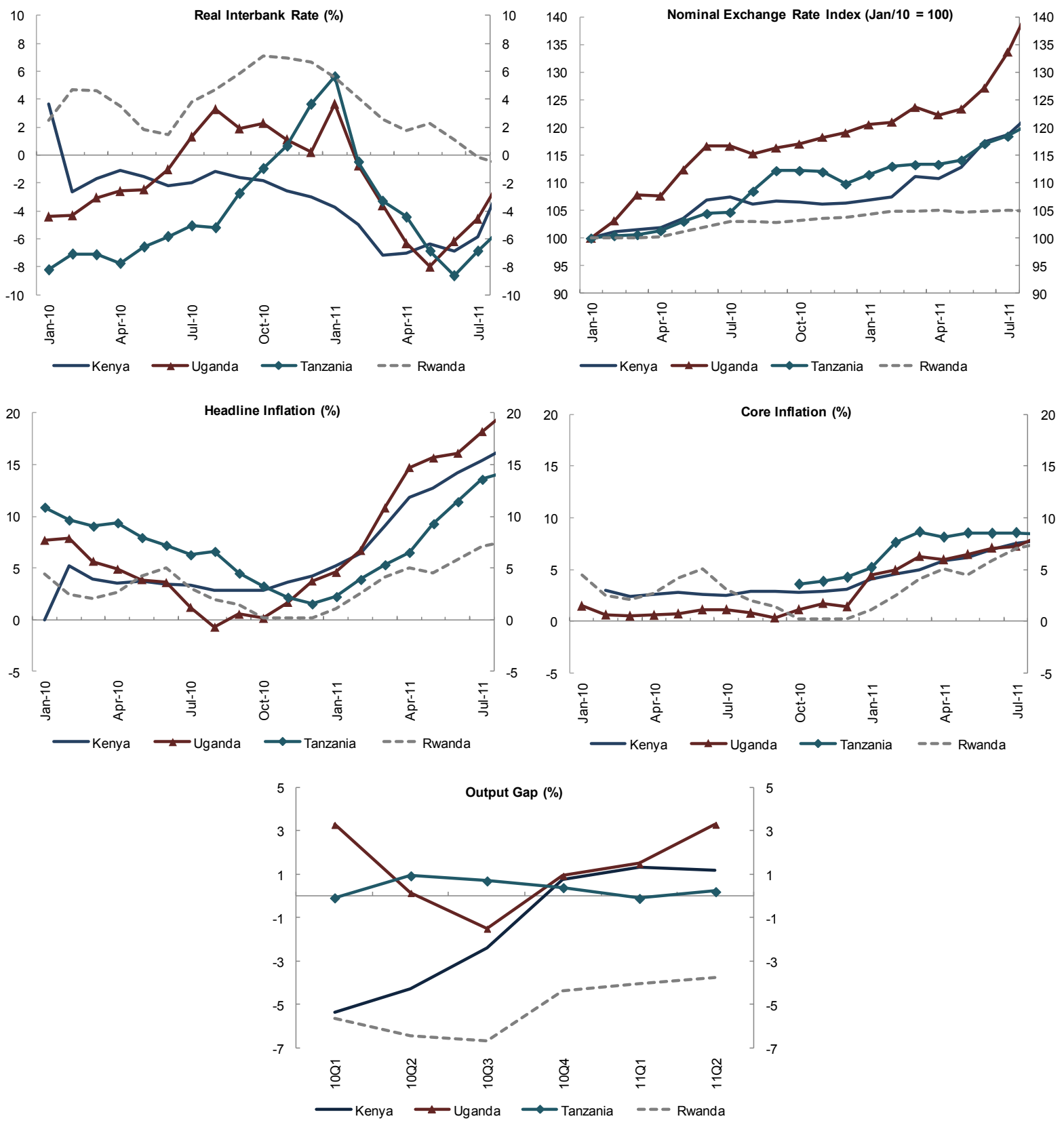

Source: IMF estimates, Haver, national authorities. 
In Kenya, on March 2011 the CBK increased its Central Bank Rate (CBR) by 25 basis points (bp) to 6 percent, reversing a lowering of $25 \mathrm{bp}$ in January $2011 .^{27}$ This move, which was accompanied by mixed signals as to the intent of the CBK, had no discernible effect on lending rates, the exchange rate, or other components of the transmission mechanism (Figure 7). ${ }^{28}$ Inflation continued to increase and the nominal exchange rate depreciated by about 10 percent in the period from March until September, further fueling inflation expectations.

Figure 7. Kenya - Selected Interest Rates (Percent)

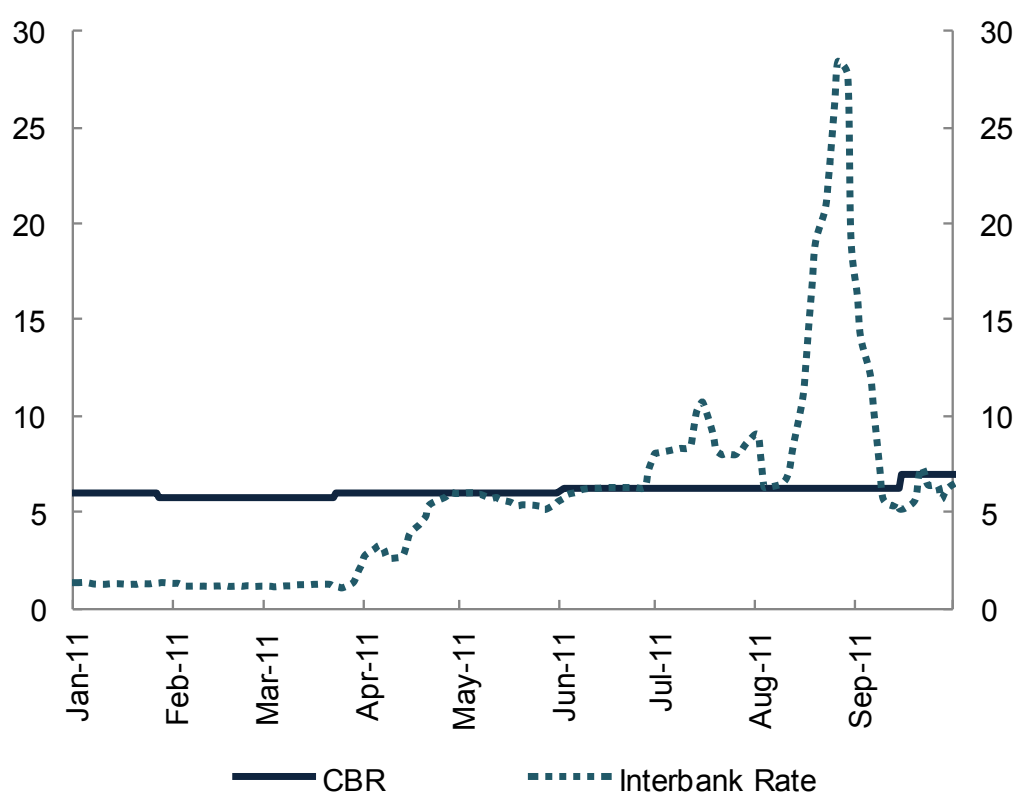

Source: IMF, Central Bank of Kenya.

By late June 2011 the CBK's beliefs that the commercial banks were funding long foreign exchange positions through the discount facility led to substantial policy movements that resulted in severe stress in the money market. Two weeks after increasing the discount rate from $6.25 \%$ to $8 \%$, (disconnecting it from the policy rate), the CBK lowered it and capped banks' access to the facility. In August 2011 the central bank resorted to stronger moves, and stopped offering reverse repos (in which the CBK buys back securities from commercial banks), changed the formula to set the discount rate (as a premium to the CBR or the interbank rate, whichever was higher), stopped publishing the discount rate and restricted access to the facility further (linking it to the banks' foreign exchange trading behavior). These moves resulted in a 2,200 bp spike in interbank rates and the increase in interbank

\footnotetext{
${ }^{27}$ There was no explicit link between the CBR and repo rates until 2012.

${ }^{28}$ In March 2011, the CBK suggested somewhat contradictorily that "this tightening will provide a solution to inflationary pressure and will stabilize the exchange rate while still protecting economic activity" (Central Bank of Kenya (2011). In July they still considered this action sufficient to mitigate soaring inflation (Central Bank of Kenya (2011a).
} 
rates had no effect on other components of the transmission mechanism; indeed the exchange rate depreciated further.

In September 2011, the central bank raised the CBR from 6.25 percent to 7 percent, while providing liquidity to the interbank market through repo operations at 5.75 percent. Such contradictory signals may have confused markets. The ongoing depreciation and inflationary pressures resulted in the decisive phase of monetary tightening, when the authorities recognized the need to clarify their policy framework and communication strategy. ${ }^{29}$

Meanwhile in Uganda the BOU also began to tighten somewhat cautiously. The central bank noted that policy was tightening, and indeed interbank rates raised some 500bp in $2011 \mathrm{H} 1$, but lending rates remained unchanged, owing perhaps to the lack of clear signaling that characterizes monetary targeting frameworks. ${ }^{30}$ In July 2011, as was mentioned, the BOU switched its policy framework to IT-lite and introduced the Central Bank Rate (CBR) to signal the stance of policy. The central bank raised the CBR in two steps from 13 percent in July 2011 to 16 percent in September 2011. The increase was intended to contain the spillovers of high food inflation to non-food prices and to support the nominal exchange rate. Consequently, the lending rate increased by 340 bp from July until September 2011, foreshadowing the larger tightening to come.

Tanzania began acting as early as $2010 \mathrm{Q} 4 .^{31}$ A sharp contraction in the real growth rate of money in late 2010 caused a blip up in the interbank rate, with a bit of pass-through to T-bill rates, but this proved short-lived even as the growth rate of money continued to fall. As money growth reached nearly zero in mid-2011, interbank (but not T-bill) rates again spiked. There was no discernible effect on lending rates, the exchange rate, or credit aggregates of these actions (except for a small down-blip in credit growth in mid-2011, Figure 8).

\footnotetext{
${ }^{29}$ At an extraordinary meeting on September 14, 2011, "The Committee observed that inflation, exchange rate, and money market volatility continued to pose a challenge for the economy. Specifically, the debt crisis in Europe continues to have an effect on the economy through the exchange rate volatility." (Central Bank of Kenya (2011c)). In October 2011, the CBK clarified the contradictory nature of its communications by stating that "this upward adjustment of the CBR was expected to provide a signal to banks that interest rates should rise and therefore reduce the expansion in credit to the private sector" Central Bank of Kenya (2011d).

${ }^{30}$ The communication strategy at the time seemed to rely on the monthly Economic and Financial Indicators Report, prepared by the Research Department. With the introduction of the new framework also came the release of a Monetary Policy Statement, signed by the Governor and providing forward guidance to market participants, in line with best practices in central banking around the world.

31 "In an environment of rising inflation, the Bank took measures to stem inflation expectations and exchange rate volatility” (Bank of Tanzania, 2012).
} 
Figure 8. Tanzania - Real Money Growth and Short-Term Interest Rates, (Percent)
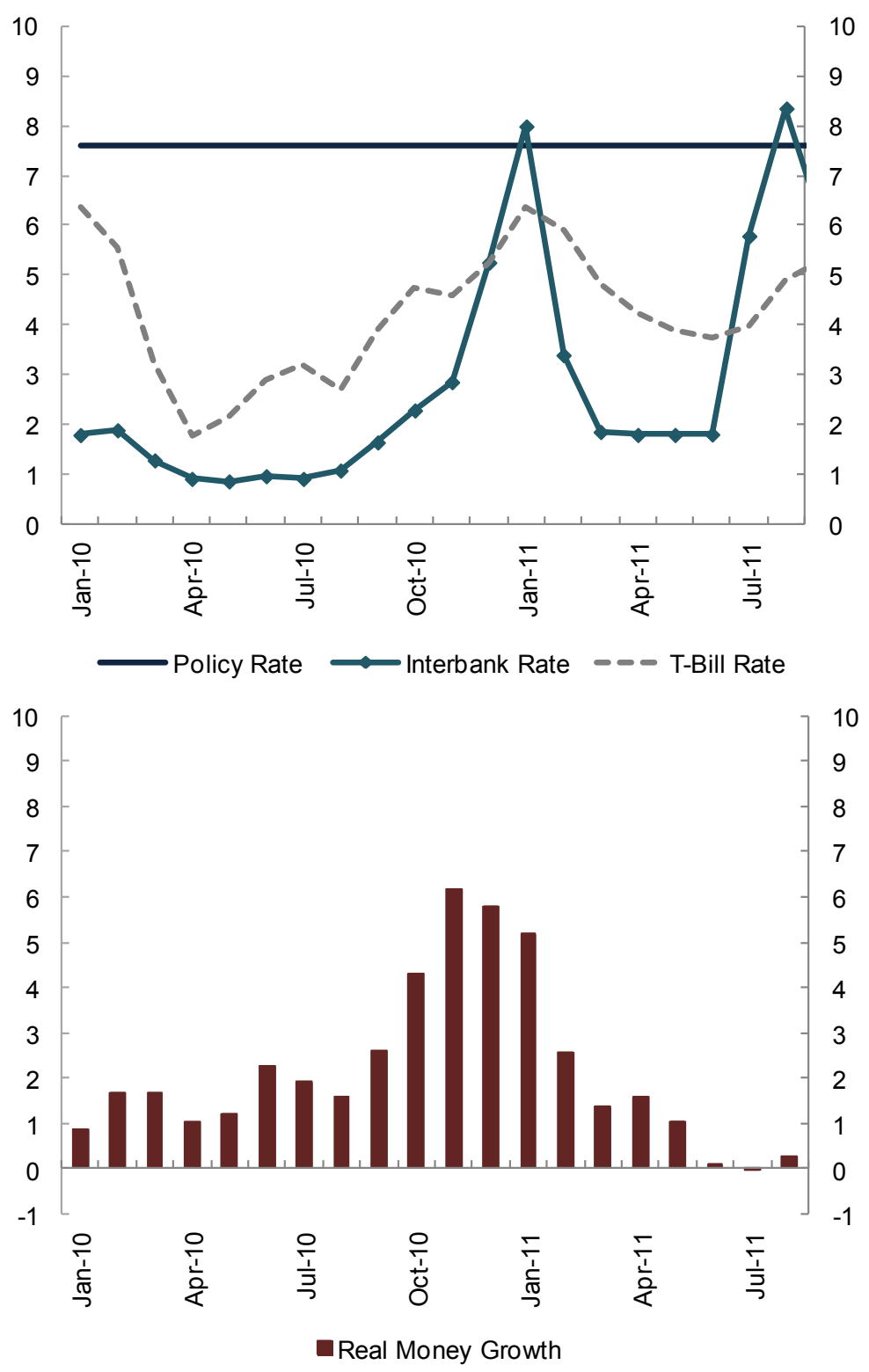

Source: IMF estimates, Haver, national authorities.

Economic developments in Rwanda paint a different picture: output was below trend, real interest rates remained positive, and the exchange rate was stable. This may have reflected a tighter monetary policy stance, as well as the de facto crawling peg exchange rate regime. It is hard to infer much about the stance of policy from monetary aggregates during this period; for example, they are not closely related to movements in short-term interest rates (Figure 9). 


\section{Figure 9. Rwanda - Real Money Growth and Short-Term Interest Rates (Percent)}

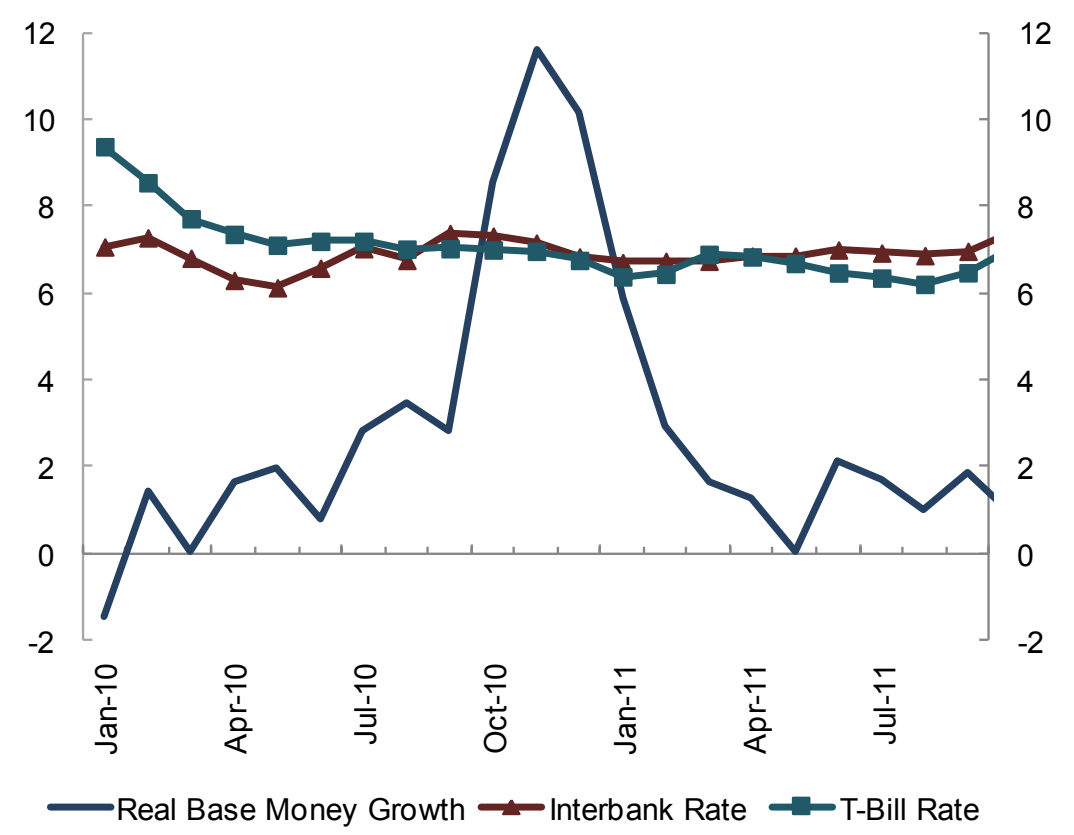

Source: IMF estimates, Haver, national authorities.

\section{B. The Event}

As 2011 unfolded, inflation accelerated on the strength of higher food and oil inflation, strong demand, weakening exchange rates, and still-negative interest rates (Rwanda is an exception, as described above). The EAC4 came to the realization that more significant and clear action was needed to stabilize the situation. After the October meeting, they took such action.

During this decisive tightening phase, the CBK increased its policy rate by $1,100 \mathrm{bp}$ to 18 percent ramped up the cash reserve requirement by 75 bps to 5.25 percent, and adjusted the discount window rate by more than 20 percent, "as decisive and immediate action is required from the monetary policy side to stem these inflationary expectations. ${ }^{32}$ Also, the Ministry of Finance lowered the foreign exchange exposure limit for commercial banks to 10 percent of core capital from 20 percent.

The Ugandan central bank, in turn, raised its policy interest rate by $700 \mathrm{bp}$ to 23 percent and stepped up its unsterilized intervention in the foreign exchange market to contain the depreciating pressures on the Shilling, stating that "the upside risks to inflation have

\footnotetext{
${ }^{32}$ Central Bank of Kenya (2011c).
} 
increased, it is necessary to tighten monetary policy further... (this) should be seen as a clear signal of the BOU's determination to bring inflation under control." 33

In Tanzania, the central bank increased the policy rate by $440 \mathrm{bp}$ to 12 percent, augmented the minimum reserve requirements on government deposits held by banks from 20 percent to 30 percent, reduced commercial banks' limit on foreign currency net open positions from 20 percent to 10 percent of core capital, tightened capital controls and increased sales of foreign exchange in the interbank market. This shift was more decisive than earlier efforts, perhaps partly because this time the authorities put more emphasis on the policy rate, as well as on the quantitative actions.

Finally, the National Bank of Rwanda took a variety of more moderate tightening measures, consistent with the much lower degree of disequilibrium throughout 2011. Again, it is hard to point to any specific measurable action with respect to money aggregates, but the central bank's policy rate was increased by 50 bp to 6.5 percent, with subsequent increases by another 100 bp by mid-2012 as "the Central Bank finds it appropriate to review its policy rate in order to keep the monetary aggregates at optimal levels to limit inflation pressures while continuing to support economic growth". 34 This increase was followed by higher short-term interest rates and the average interbank rate climbed by $370 \mathrm{bp}$ to 11.3 percent in the period between 2011Q4 and 2012Q4.

Having identified the event as period of clear policy tightening, we now turn to an assessment of the various channels of transmission of monetary policy across our group of countries. A brief summary of the channels is described in Box 3.

\footnotetext{
${ }^{33}$ Bank of Uganda (2011b).

${ }^{34}$ National Bank of Rwanda (2011a).
} 


\section{Box 3. An Overview of the Transmission Mechanisms of Monetary Policy}

The transmission mechanism of monetary policy refers to the various channels through which changes in the monetary policy stance influence aggregate demand and inflation. The range of channels can be grouped into five categories: (1) interest-rate channel, (2) exchange-rate channels, (3) expectations channel, (4) credit channels, (5) asset price channels and (6) the risk-taking channel. The asset-price and risk-taking channels operate through highly developed non-bank financial markets and institutions, and given the limited nature of these in the EAC4 countries we will not attempt to find evidence of their existence or go into details about their functioning. ${ }^{35}$

The interest rate channel states that, given price or wage rigidities, changes in the monetary policy stance (reflected in short-term nominal interest rates) affect real interest rates, which in turn feed through to aggregate demand and prices by changing firms' and households' investment and consumption decisions. ${ }^{36}$ In Keynesian frameworks, these deviations of aggregate demand from the potential output of the economy (the output gap) will result in inflationary/deflationary pressures through a standard Phillips Curve mechanism. In this context, a tightening of the monetary policy stance translates into higher interest rates, slower aggregate demand and reduced inflationary pressures.

In addition, with capital mobility, arbitraging opportunities imply that changes in real interest rates also affect the exchange rate, such that increases in local interest rates will tend to appreciate the currency. In turn, movements in the exchange rate will directly affect inflation by changing the cost of imports and will, by moving the real exchange rate, affect net exports and aggregate demand. Accordingly, a contractionary monetary policy would translate into an appreciation of the currency, lower net exports and aggregate demand (opening up a negative output gap), and lower inflation. This is the exchange rate channel.

Credit channels encompass a variety of mechanisms that highlight the role of asymmetric information in financial markets and its consequences for the transmission of monetary policy to the rest of the economy: the bank lending channel, the balance sheet channel and the cash flow channel. These three together postulate that changes in monetary policy will translate into changes in aggregate credit, aggregate demand and hence, inflation. According to the bank lending channel, as long as banks cannot perfectly substitute deposits with other sources of funds, changes in the monetary policy stance translate into changes in the amount of banks' reserves and deposits, altering their ability and willingness to lend. In this way, a tightening of monetary policy will translate into a lower availability of credit, slower aggregate demand and lower inflation.

A byproduct of the bank lending channel is credit rationing, which occurs in instances where borrowers are denied loans even when they are willing to pay higher interest rates, as these tend to foster adverse selection and moral hazard. When monetary policy is tightened,

\footnotetext{
${ }^{35}$ See, for example, Ceccetti (1995) and Mishkin (1996).

${ }^{36}$ According to the expectations theory of the term structure of interest rates, long-term interest rates are an average of expected short-term interest rates.
} 
increases in interest rates will discourage good-quality borrowers from demanding loans, and given the imperfect monitoring capacity of the banks, they will respond by curtailing credit to the remaining pool of participants. This phenomenon can be particularly relevant in cases, such as in the EAC4, where mitigating institutions, such as credit reference bureaus, may not function well.

The balance-sheet channel and the cash-flow channel work through the effects of monetary policy on the net worth of households and firms by altering the value of collateral that can be pledged to obtain credit. According to these, increases in interest rates translate into lower values of collateral and tighter access to credit, which in turn result in lower aggregate demand and inflation.

Finally, the strength of these different channels is determined to a large extent by the private sector's expectations of future policy decision, which can be thought as a separate channel of transmission (the expectations channel). Medium and long-term interest rates are the rates that matter for private sector decisions, which are mainly driven by expectations of future short rates. Expectations about the future also matter greatly for exchange rate determination and for the behavior of inflation, the ultimate concern of monetary policy makers. Yet monetary policy has direct control only over very short-term interest rates (usually overnight, sometimes a week). To have a noticeable impact on longer rates, policy decisions must signal the stance of policy over the medium term. This is the main reason why the communication strategy of the central bank is of first-order importance.

Figure 10. A Basic Diagram of the Monetary Transmission Mechanism

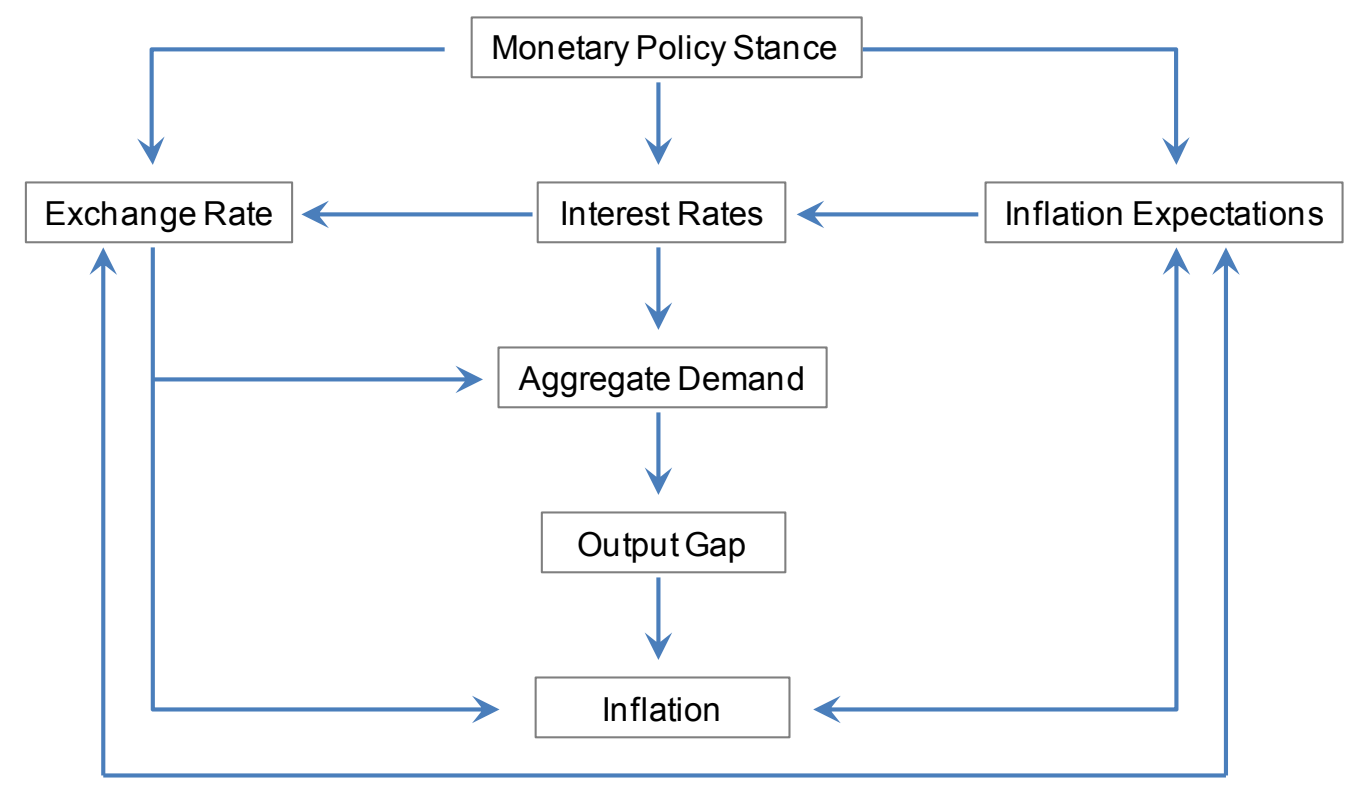


IV. The OUTCOME

Figure 11. EAC4 - Selected Economic Indicators (Part II)
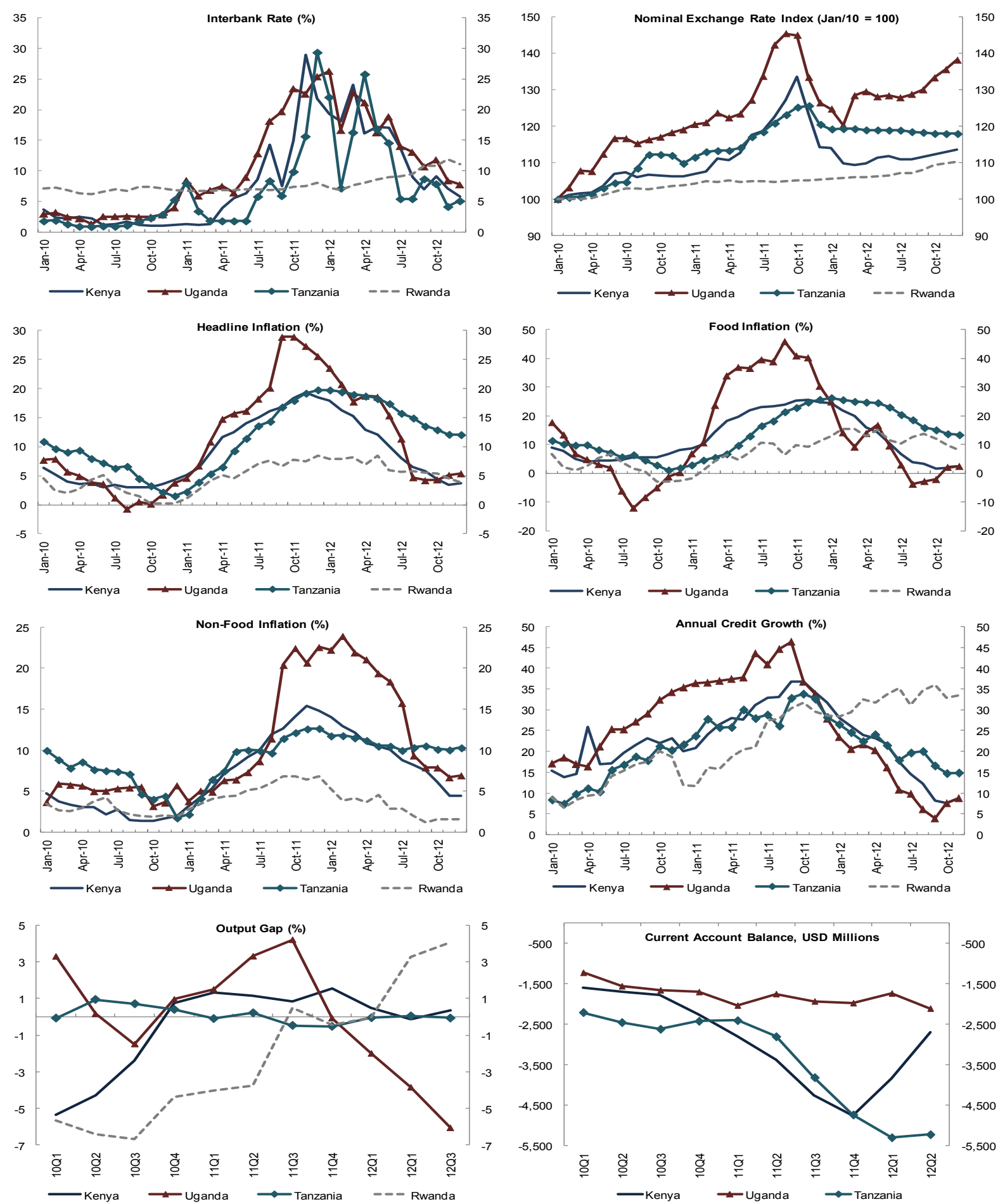

Source: IMF estimates, Haver, national authorities. 


\section{A. The interest rate channel}

In Uganda and Kenya, the pass-through from policy rates to money market interest rates was fast and complete (Figure 12). Tanzania's battery of measures also transmitted quickly to money market rates, and in Rwanda short-term interest rates responded to the announced policy tightening. ${ }^{37}$ Banking interest rates also responded swiftly to the monetary policy contraction in Kenya and Uganda. ${ }^{38}$ It is worth noticing that in Kenya, Uganda and Tanzania deposit rates have been below policy rates during and after the policy episode, pointing to some sort of inefficiency in the pricing mechanisms of the banking system (Figure 13). ${ }^{39}$

\footnotetext{
${ }^{37}$ It should be noted that T-bill rates might be responding as well to the suspension of foreign aid flows to Rwanda announced in the final quarter of 2012.

${ }^{38}$ Further upward adjustments were registered in 2012.

${ }^{39}$ It may also be a reflection of the structural liquidity surpluses mentioned in Section III.B.
} 
Figure 12. EAC4 - Money Market Interest Rates (Percent)

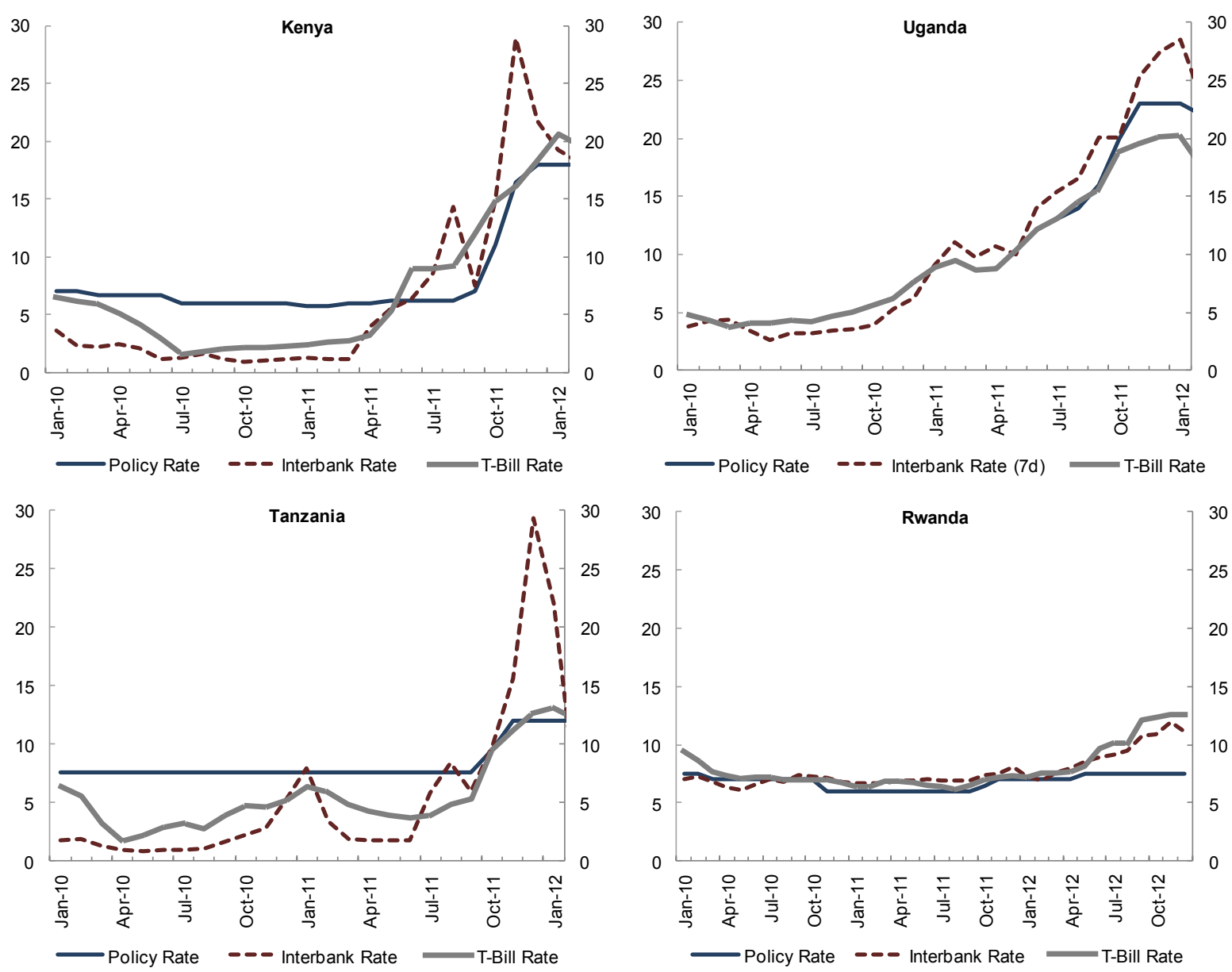

Source: IMF estimates, Haver, national authorities.

The relevance of the policy regime in analyzing the transmission of policy becomes evident in the case of the non-response of banking lending rates in Tanzania and Rwanda, even as deposit rates responded, somewhat marginally, to the tightening. Cotarelli and Kourelis (1994) show that this behavior can be attributed to the volatility of money market rates, which limits their information content regarding the stance of monetary policy and which is characteristic of the quantity-based monetary frameworks in place in these two countries. The presence of a high level of noise in money market rates can also hinder the degree of money market development, another structural feature identified in the literature as relevant in explaining the transmission of monetary policy impulses to lending rates. ${ }^{40}$

\footnotetext{
${ }^{40}$ Other structural features identified in the literature to explain this "stickiness" of lending rates include the degree of financial liberalization and of competition in the banking system.
} 
Figure 13. EAC4 - Banking Interest Rates (Percent)
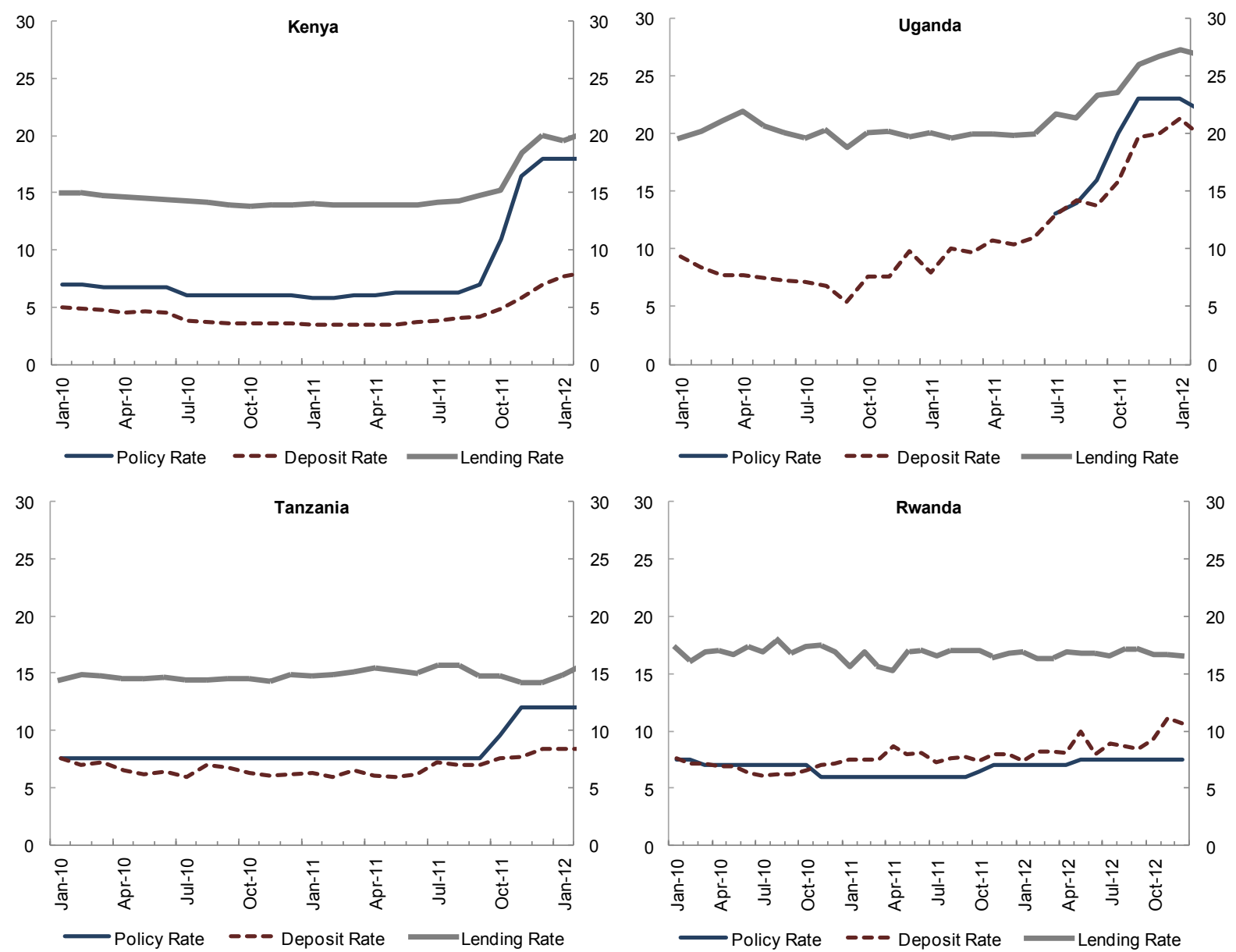

Source: IMF estimates, Haver, national authorities.

The tightening episode is also suggestive about the effects of tighter monetary conditions in aggregate economic activity (Figure 14). In all cases, though less so in Tanzania, negative real interest rates are associated with expansionary phases in activity, while positive and increasing real interest rates coincide with output below potential. Also, the evidence suggests that the effects of tighter policy transmit to activity fast; in most cases the transmission lag was one quarter. High frequency data also points in this direction as real imports, a crude proxy of domestic demand, point to a much slower dynamism after the tightening measures were adopted, although somewhat later in the case of Tanzania (Figure $15)$. 
Figure 14. EAC4 - Real Interest Rates and the Output Gap (Percent) ${ }^{41}$
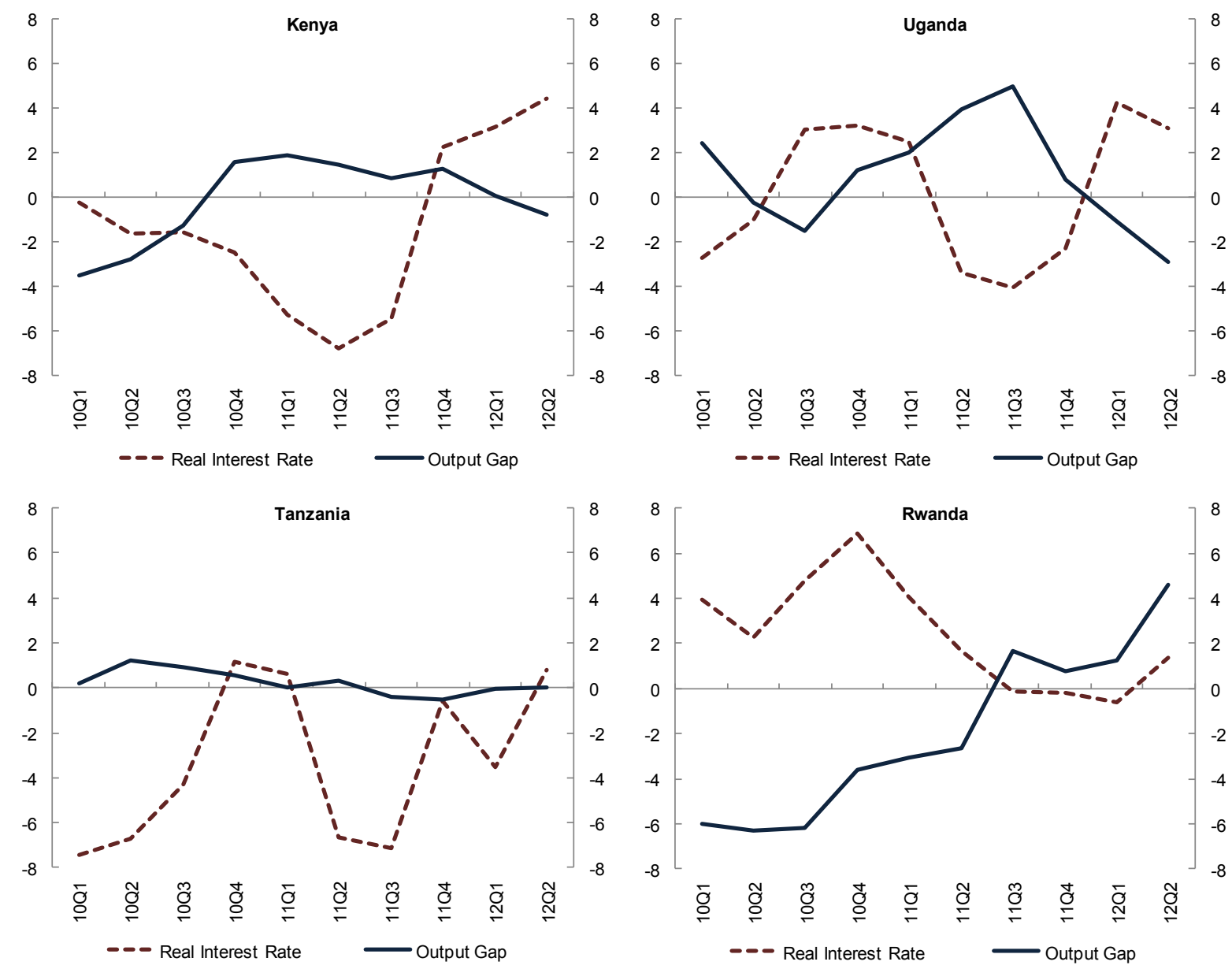

Source: IMF estimates, Haver, national authorities.

${ }^{41}$ Real interest rates are interbank rates deflated by headline inflation. 
Figure 15. EAC4 - Real Import Growth (YoY, Percent) ${ }^{42}$

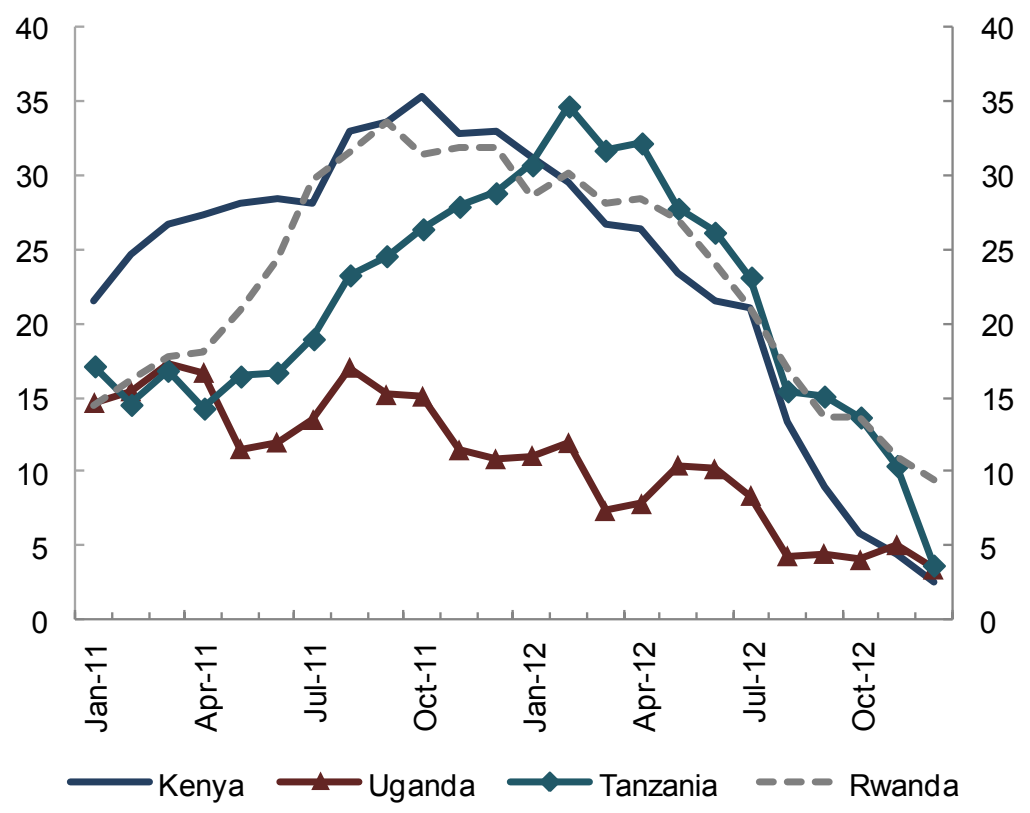

Source: IMF estimates, Haver, national authorities.

We also find support for the existence of Phillips Curve-type mechanisms in Kenya and Uganda, and less so in Rwanda and Tanzania, even though the transmission lags appear to be longer (Figure 16). In Kenya and Uganda, positive or increasing output gaps correlate with increases in non-food inflation two to three quarters ahead.

\footnotetext{
${ }^{42}$ The monthly nominal data is deflated with the US CPI.
} 
Figure 16. EAC4 - Non-Food Inflation and the Output Gap (Percent)
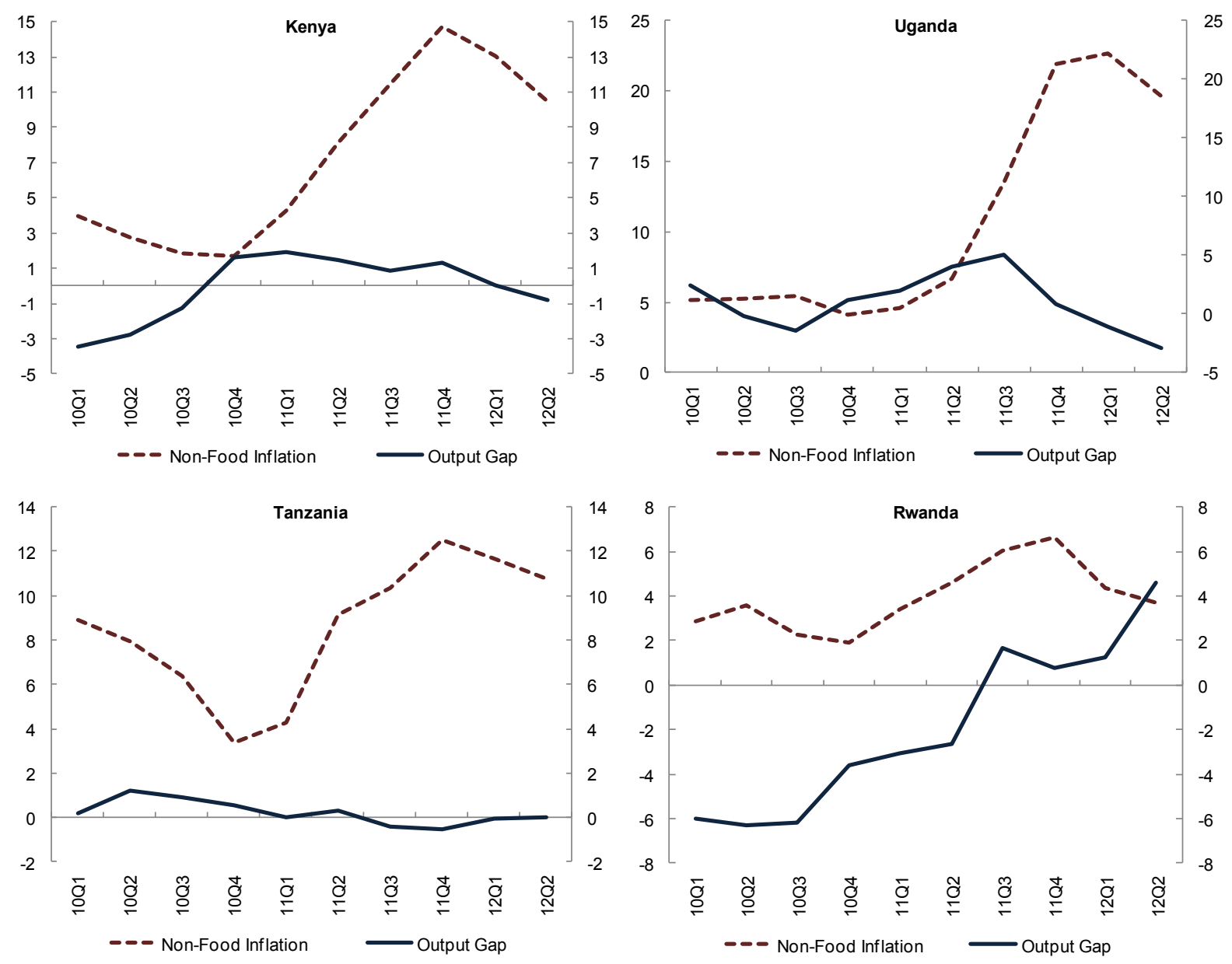

Source: IMF estimates, Haver, national authorities.

\section{B. The Exchange Rate Channel}

The event study also points to the existence of the exchange rate channel. In Kenya, Uganda and Tanzania, the increase in short-term interest rates was associated with a contemporaneous appreciation of the currency. Notably, this took place during the decisive tightening phase in 2011Q4, but not earlier when policy was more cautious and less clearly signaled (Figure 17). Pass-through from the exchange rate movements to inflation is also apparent in the cases of Kenya, Uganda and Tanzania, and the evidence suggests it was rather fast, occurring with a lag of one month (Figure 18). ${ }^{43}$ Lastly, the case of Rwanda is harder to disentangle, not surprisingly given the quasi-pegged exchange rate policy regime.

\footnotetext{
${ }^{43}$ A slight improvement in global risk appetite might have also contributed to the strengthening of the currencies (see Section V).
} 
Figure 17. EAC4 - Interest Rates (Percent) and Exchange Rates
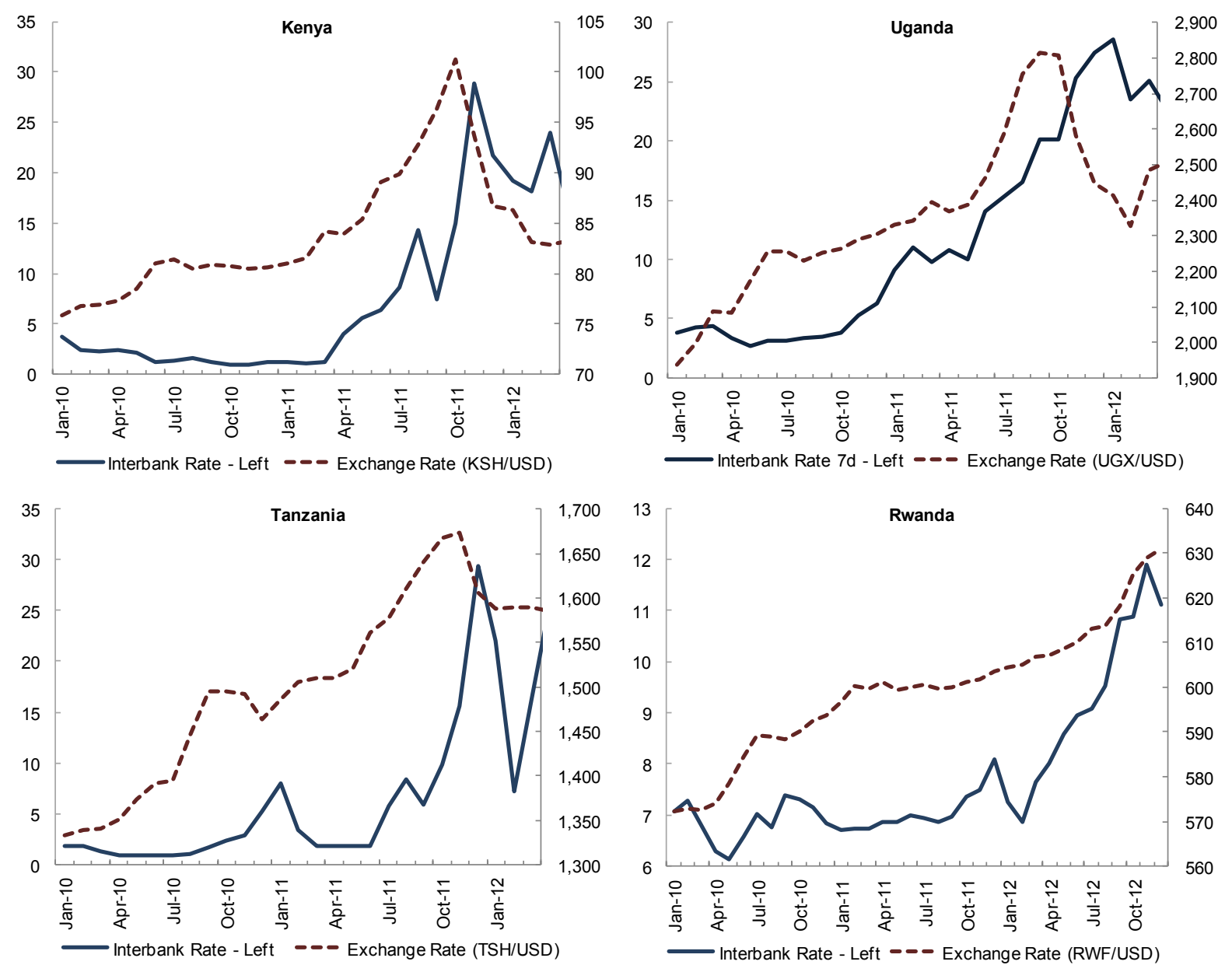

Source: IMF estimates, Haver, national authorities. 
Figure 18. EAC4 - Headline Inflation and Exchange Rate Change (YoY, Percent)
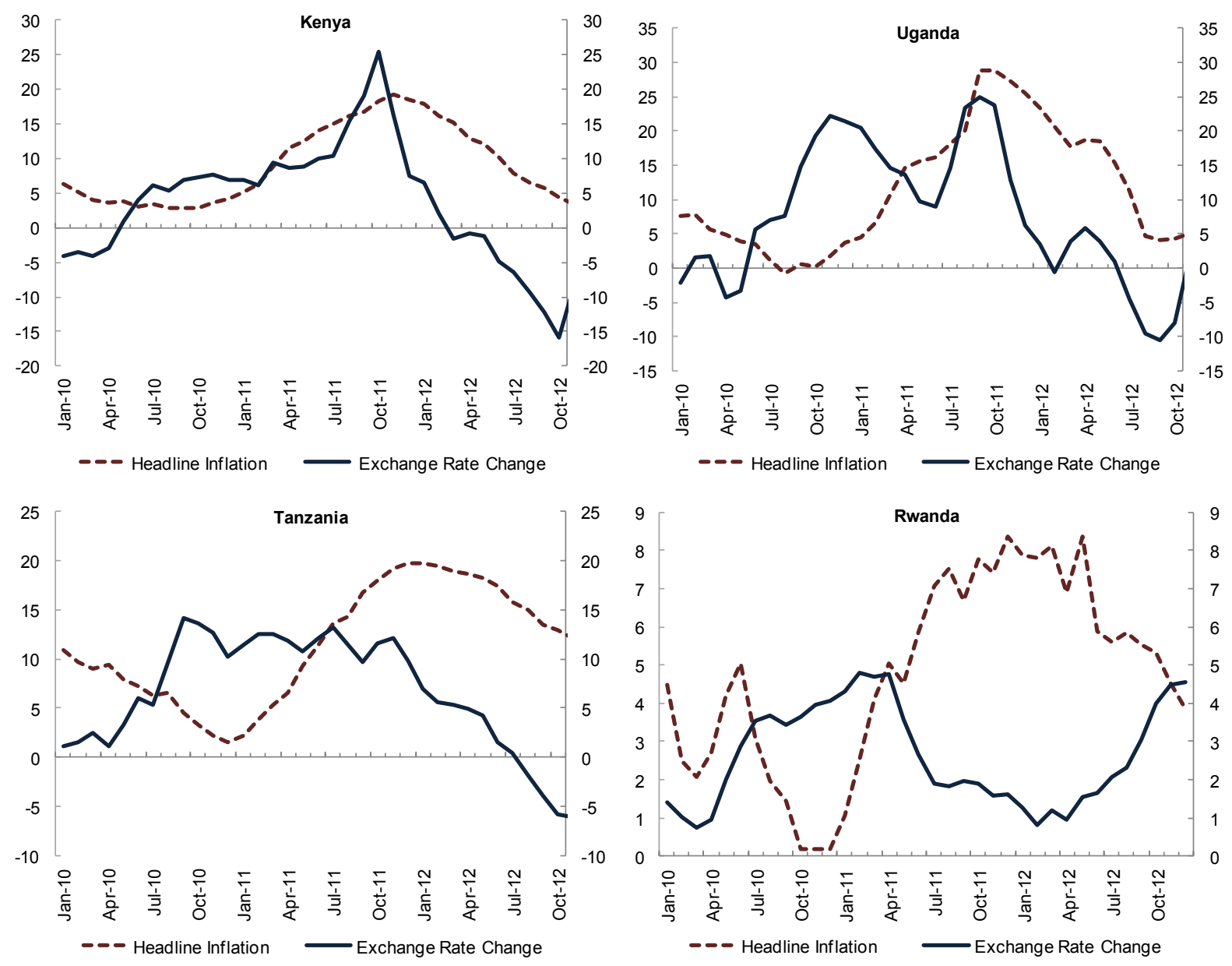

Source: IMF estimates, Haver, national authorities.

\section{The Credit Channel}

The data also suggestive of the existence of the credit channel in Kenya, Uganda and Tanzania. In these three countries growth in credit to the private sector peaked soon after the policy contraction started and decelerated substantially as the monetary authorities steppedup the pace of tightening. Accordingly, during the 2011Q3 to 2012Q3 period credit to the private sector growth in Kenya, Uganda and Tanzania decelerated (Figure 19). There are also signs of credit rationing in the case of Tanzania: even though lending rates did not respond to the tightening, there was a meaningful impact on the quantity of credit extended to the economy.

Finally, in Rwanda the tighter policy stance does not appear to have translated into slower credit, perhaps reflecting the less significant tightening, the less clear policy regime, and possibly also the Government's previously mentioned policy of directly promoting increased credit growth. 


\section{Figure 19. EAC4 - Interest Rates and Credit Growth (Percent)}
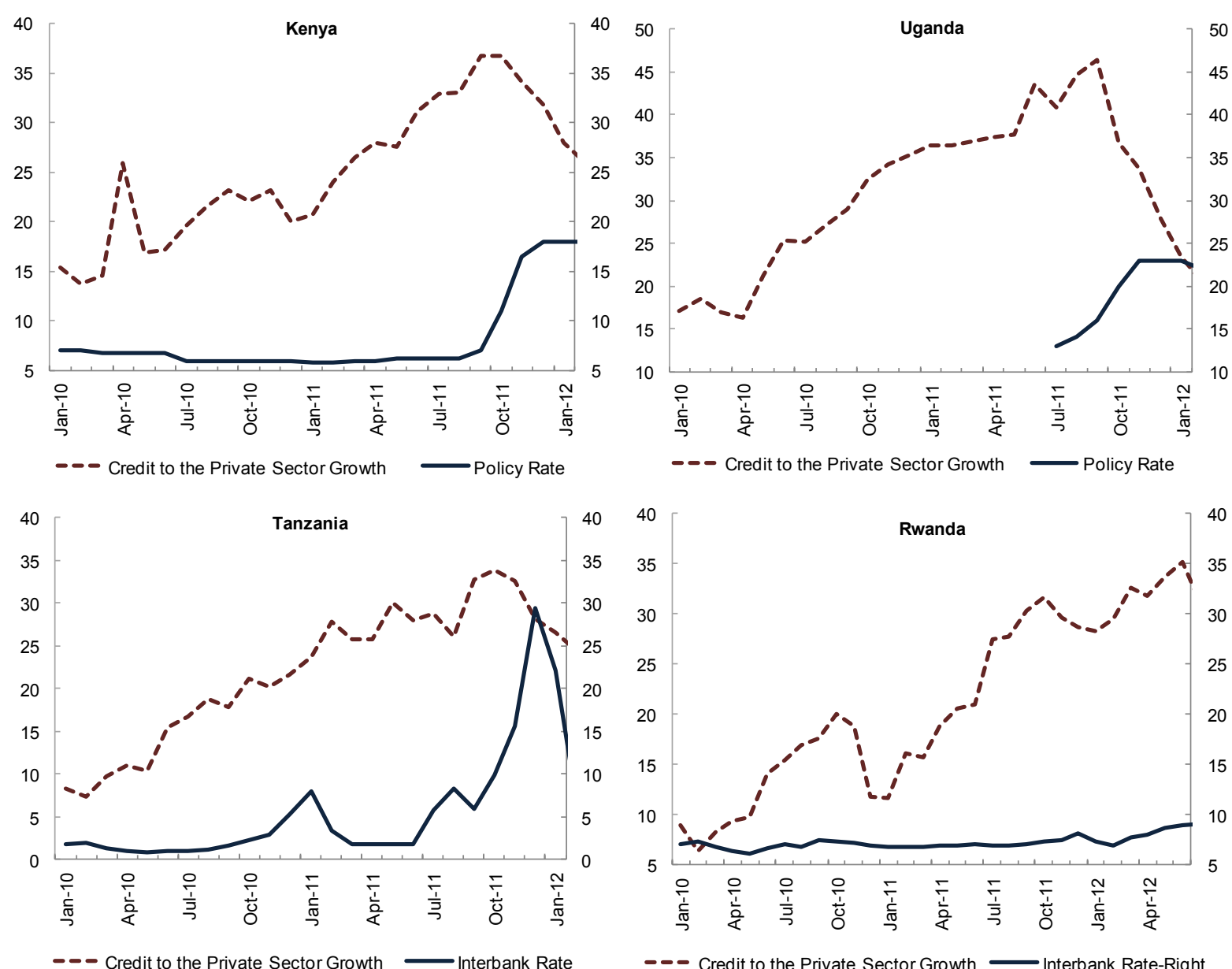

- - Credit to the Private Sector Growth Interbank Rate-Right

Source: IMF estimates, Haver, national authorities.

\section{A Summary of the Findings}

To summarize, we have identified a time when three of the EAC4 broke from previous behavior and executed more-or-less clearly signaled monetary policy contractions with the explicit intent of reducing inflation. We find clear evidence of most elements of the standard transmission mechanism in most of the countries, and the deviations are largely explicable in terms of the nature of the policy adjustment and regime. We present a summary of the findings in Table 6.

The transmission was the clearest in Kenya and Uganda, where the regimes most resembled inflation targeting in that the authorities prioritized inflation, emphasized the role of the policy rate, allowed the exchange rate a large degree of flexibility, and broadly avoided multiple objectives.

It was less clear in Tanzania, where the effects on some interest rates, activity, the exchange rate, and inflation are still broadly evident, but lending rates failed to respond, perhaps 
reflecting the fact that the money targeting regime led to highly volatile short-term interest rates and hence a less clear signaling of the policy stance. Interestingly, we see some evidence of an exchange rate response to the tightening despite the closed capital account.

Rwanda presents a control along several dimensions: the tightening was less significant and the hybrid regime did not provide a clear signal. A quasi peg and direct influence on private sector credit, in particular, mean that it is harder to infer policy from short-term interest rates (or anything else). And in the event, the results of the tightening were less evident.

\section{Table 6. EAC4 - Monetary Policy Transmission Channels}

\begin{tabular}{|c|c|c|c|c|c|c|c|c|}
\hline \multirow[b]{2}{*}{ Channel } & \multicolumn{2}{|c|}{ Kenya } & \multicolumn{2}{|c|}{ Uganda } & \multicolumn{2}{|c|}{ Tanzania } & \multicolumn{2}{|c|}{ Rwanda } \\
\hline & Evidence & Lag & Evidence & Lag & Evidence & Lag & Evidence & Lag \\
\hline Interest Rate Channel: Money market rates & Yes & 1 quarter & Yes & 1 quarter & Yes & 1 quarter & Yes & 1 quarter \\
\hline Interest Rate Channel: Deposit rates & Yes & 1 quarter & Yes & 1 quarter & Yes & 1 quarter & Yes & 2 quarter \\
\hline Interest Rate Channel: Lending rates & Yes & 2 quarter & Yes & 2 quarter & No & n.a. & No & n.a. \\
\hline Interest Rate Channel: Activity & Yes & 3 quarters & Yes & 3 quarters & Yes & 1 quarter & Yes & 1 quarter \\
\hline Exchange Rate Channel: Arbitrage & Yes & 1 quarter & Yes & 1 quarter & Yes & 1 quarter & n.a. & n.a. \\
\hline Exchange Rate Channel: Pass-through & Yes & 1 quarter & Yes & 1 quarter & Yes & 1 quarter & Inconclusive & 6 quarters \\
\hline Credit Channel & Yes & 1 quarter & Yes & 1 quarter & Yes & 1 quarter & n.a. & n.a. \\
\hline Phillips Curve & Yes & 2-3 quarters & Yes & 2 quarters & Inconclusive & n.a. & Inconclusive & n.a. \\
\hline
\end{tabular}

Source: Authors' estimates

An interesting feature of the event that could merit further analysis is the potential credibility effects associated to the coordinated nature of the tightening and if these played a role in lending potency to the transmission mechanism. However, under the assumption that the exante credibility gains implied were similar to all the central banks involved, these appear to have manifested most in those countries with the more transparent monetary regimes, namely Kenya and Uganda.

The event study also illustrates the variety of instruments and policies that were used by authorities to rein in inflation and exchange rate pressures, which included the adjusting and introduction of new operating frameworks (Kenya and Uganda), movements in reserve requirements (Kenya and Tanzania), capping of lending rates (Kenya), discretionary interventions in the foreign exchange market (Kenya, Uganda and Tanzania), changes in the net open position limits of financial intermediaries (Kenya, Uganda and Tanzania) and tightening of capital controls (Tanzania). From a methodological point of view, this active use of a wide set of instruments under differing policy regimes with multiple objectives, along with the suggested quasi-contemporaneous nature of the transmission mechanism suggest that extra care should applied used when using standard statistical procedures, such as VARs, to measure the effects of policy, especially when those studies are conducted for country groups.

Finally, it is often asserted that the high levels of excess reserves usually observed in SSA countries prevent the operation of the monetary transmission mechanism, for example because tightening policy may amount to "pushing on a string" as banks respond to a contraction by withdrawing excess reserves. ${ }^{44}$ The episode we examine here suggests that excess reserves need not impair the transmission mechanism. As Figure 20 shows, there are

${ }^{44}$ Saxegaard (2006). 
indeed substantial reserves in excess of required levels in all four countries, with large variations across time and countries. However, the available data suggests this was not the case in the period under study. While in Kenya, excess reserves fell during 2011 they rose in Uganda and varied around 30 percent of required reserves during the peak of the tightening phase, higher than they had been since $2007 .^{45}$

Figure 20. Excess Reserves (Percent of Required Reserves)
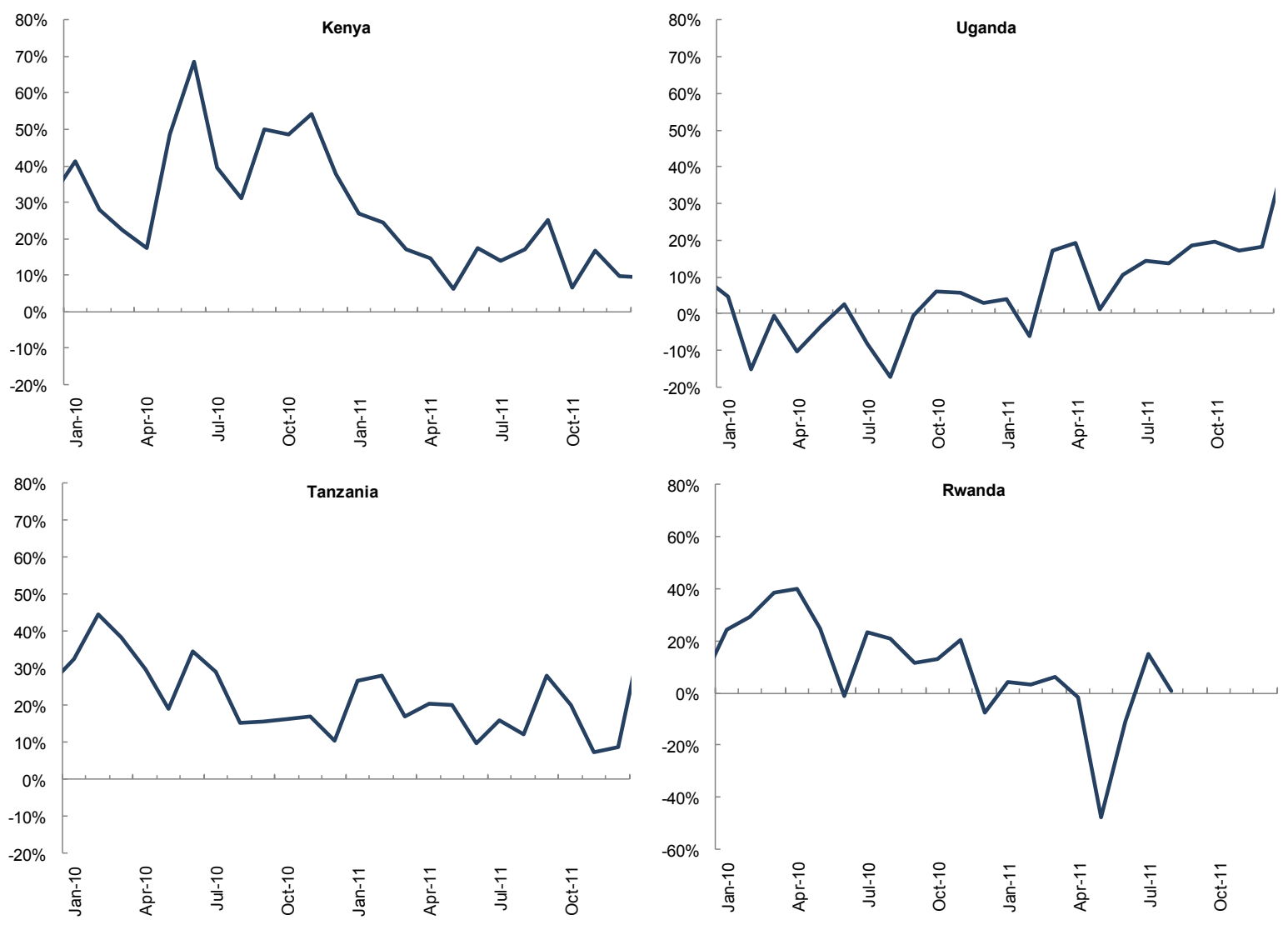

Source: IMF estimates

\section{On The Role OF Global Risk ApPetite AND Supply SHOCKS}

As was previously mentioned, the backdrop against which the coordinated tightening took place was challenging in the sense that the authorities faced both a supply shock and a negative balance of payments shock in the context of accommodative policies and growing imbalances. We now discuss alternative interpretations of the events, which emphasize the direct role of these two factors in the inflationary and broad macroeconomic dynamics, and

\footnotetext{
${ }^{45}$ This evidence suggests that these "excess" reserves may be an equilibrium phenomenon reflecting factors such as risk aversion on the part of banks and structural deficiencies in the functioning of the interbank market. Addressing these deficiencies that create excess liquidity is likely important for the promotion of financial development but, judging from this episode, it is not necessary for the transmission of monetary policy.
} 
by extension minimize the role played by monetary policy. We argue that these alternative interpretations cannot provide a coherent account of the events we have documented.

The first alternative view focuses on the role of capital flows and risk aversion in explaining the exchange rate dynamics both during the run-up and following the coordinated tightening. The year 2011 was one of increased global risk aversion. Events such as the rising political tensions in the Middle East associated with the Arab Spring, the sovereign debt crisis in Europe, and the downgrading of the credit rating of major industrial economies likely translated into a negative shock to the balance of payments in these economies, and, according to this view, account for the behavior of the exchange rate during the run up. While compelling, this alternative view does not coincide with the timing of events in the EAC. The currencies of Kenya, Uganda and Tanzania started to weaken in 2010, well in advance of the episode, standing during 2010 and 2011 amongst the most depreciated currencies in the emerging and frontier markets world (excluding fixed exchange rate regimes, Figure 21). Exchange rate pressures did exacerbate in March 2011 in Kenya after the Libyan civil war broke off and Moody's downgraded Spain's sovereign rating and in June 2011 in Uganda and Tanzania, as Greece started to slide into its second bailout. All along however, real interest rates in these countries remained in negative territory, which either added to or amplified the pressure on the exchange rate.

Figure 21. Emerging and Frontier Markets Exchange Rates, (Index, Jan. 2010=100)

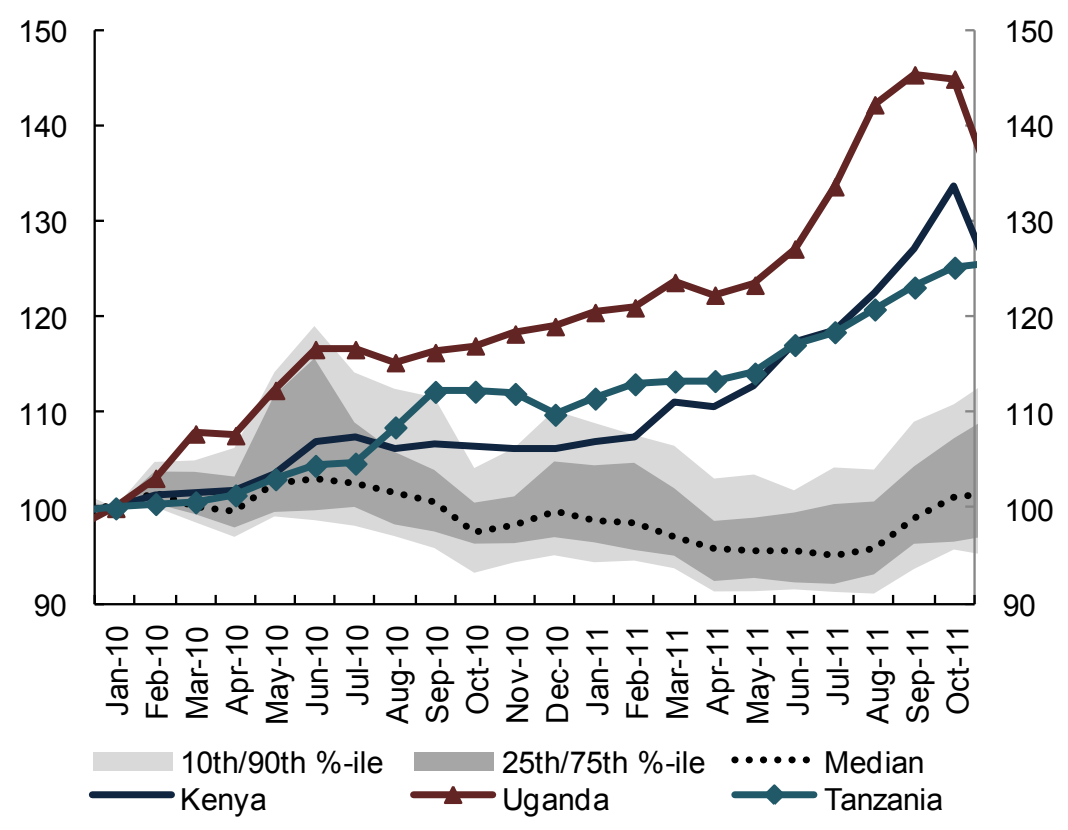

Source: IMF, Haver.

Global risk appetite, as proxied by the VIX Index, deteriorated markedly in August and September as the credit ratings of the US, Japan and Italy were downgraded and Europe's debt crisis intensified (Figure 22). Tensions in international capital markets eased by late September and early October as major central banks expanded their quantitative easing programs. However, pressures on EAC4 exchange rates did not abate and the Kenyan 
shilling reached its lowest level in seventeen years on October 2011, a week and a half after the VIX reflected the improvement in risk appetite. Furthermore, the currency rallied after the October 12 announcement of the coordinated tightening, with the shilling strengthening by $20 \%$ through year-end and the tightening measures announced in November $1^{\text {st }}$ and December $1^{\text {st }}$ provided further support to the exchange rate, even though the VIX continued to trade above average levels (it would return to pre-crisis levels in early 2012).

\section{Figure 22. VIX (Index) and EAC4 Exchange Rates}
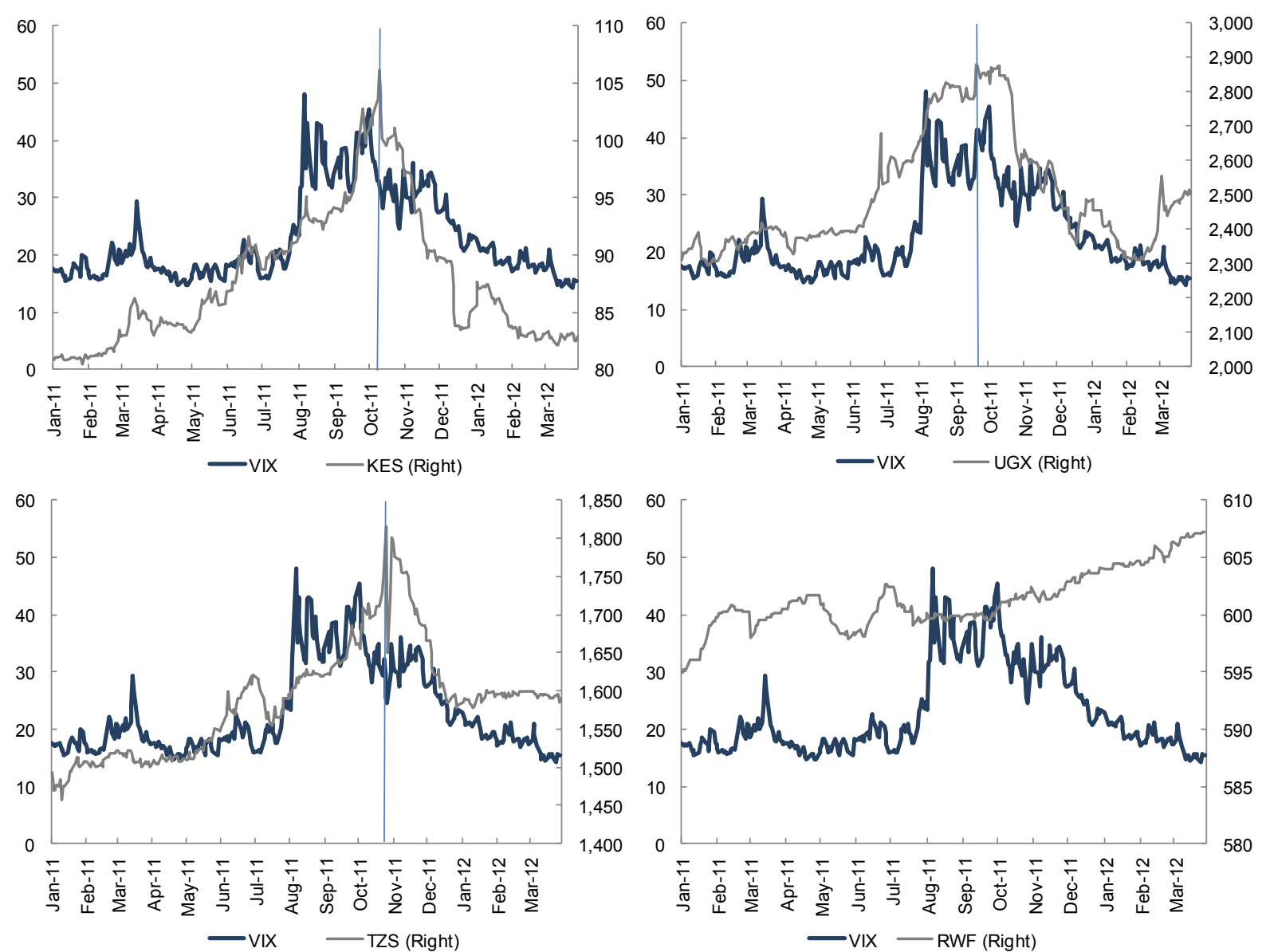

Source: Bloomberg.

A similar argument applies to the Ugandan shilling, which started to appreciate following the October $12^{\text {th }}$ announcement of the coordinated tightening after remaining range-bound around historical lows for the previous three weeks. The Tanzanian shilling, on the other hand, continued to weaken even after the announcement of the coordinated policy, interrupting its slide only after the battery of measures was announced on the week of October $24^{\text {th }}$. Moreover, the dynamics of reserves in Rwanda, which may be a useful direct measure of exchange market pressures in that country, do not show a substantial outflow in the second half of 2011 (though volatile aid dynamics may obscure the picture).

An alternative argument highlights the predominant role of the supply shock (the increase in commodity prices) in the region's inflationary dynamics, rather than monetary policy. On this view, the inflationary pressures were not a reflection of vigorous economic activity and 
loose monetary policy but a result of the higher food and fuel prices. Likewise, inflation fell once the food and fuel price shock unwound and not because of the tighter monetary policy stance.

As discussed in section III, we find that commodity prices were not the only source of inflationary pressures during the run up. Core inflation also increased substantially, almost doubling during the course of a year, and in all cases overshooting the inflation target. Likewise, after the coordinated tightening core inflation fell significantly (less apparently in Tanzania, where the policy signaling is less clear, see Figure 23). We interpret the behavior of core inflation, together with the path of economic activity and the exchange rate, as clear evidence of the primacy of monetary policy during these events.

In addition to the behavior of core inflation, it can also be argued that movements in food and fuel inflation are themselves influenced by the monetary policy stance. In the case of imported food (and fuel), monetary policy influences their domestic price through the exchange rate, whereas in the case of locally produced (and not-fully-traded) food, monetary policy also influences their price via aggregate demand pressures. In this case, disentangling the contribution of monetary policy from that of supply shocks cannot solely be based on separating food/fuel and core inflation, and a more structural approach is required. Andrle et al (2013) do just that: they apply a structural model to events in Kenya during the run up, and find that monetary policy accounts for much of the inflation dynamics, including the behavior of domestic food prices. This confirms our view of the events in the EAC. ${ }^{46}$

To conclude, while the swings in global risk aversion and the food and fuel supply shock during 2011 did play an important role during the episode under study, they are only part of the story. We argue that they compounded what was already a vulnerable situation. In any case, we do not wish to minimize their contribution to the events under study, but rather to concentrate in what we consider is the main policy lesson from this episode, which is that monetary policy does matter. We believe this is an important contribution to the understanding of the macroeconomics of LICs.

\footnotetext{
${ }^{46}$ In ongoing work, we are applying the approach in Andrle et al (2013) to provide a model-based account of all four EAC countries throughout the period. This analysis can help shed light on the relative importance across these countries of the various factors we have discussed.
} 
Figure 23. EAC4 - Headline and Core Inflation (YoY, Percent)
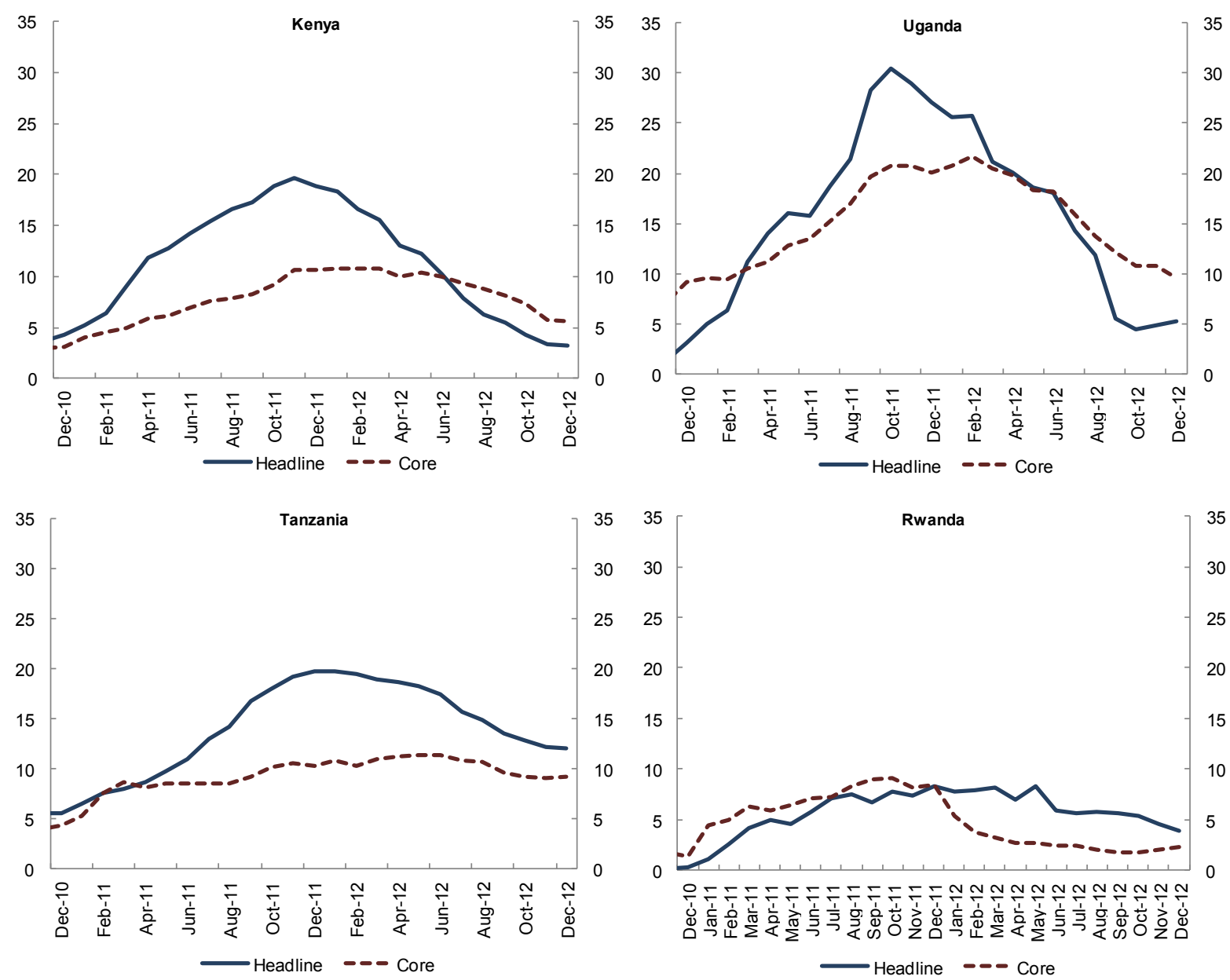

Source: IMF estimates, national authorities.

\section{Conclusions}

We find clear evidence of a working transmission mechanism: after a large policy-induced rise in the short-term interest rate, lending and other interest rates rise, the exchange rate tends to appreciate, output growth tends to fall, and inflation declines. The standard features of the transmission mechanism are most evident in the cases of Kenya and Uganda. In Tanzania the exchange rate seems to respond to adjustments of the monetary policy stance and we see some signs of the effects of policy in output (possibly through credit rationing), while in Rwanda the evidence is less suggestive.

The case study illustrates that the policy framework makes a big difference to the strength of transmission of policy decisions. Where countries target money, such as Tanzania and Rwanda, short rates are less likely to be informative or to move long rates. And when a policy tightening is not accompanied by good communication or a coherent framework it has less clear effects. The difficulty in interpreting the different measures of policy in a context of imperfect asset substitution and multiple instruments may impact not only our ability to discern events but the capacity of interest rates to clear markets and signal policy. 
Perhaps surprisingly, we have not had much cause to refer to fiscal pressures or "fiscal dominance" in tracing the transmission mechanism. We acknowledge that fiscal policy often creates challenges for policy in countries like the EAC4. Here, though, it may have been prior to the decisive tightening phase: A desire to keep treasury bill rates (among all interest rates) low may have led to occasional inconsistencies in central bank operations at specific points in time, e.g., when policy was tightened through some operations and the effects on treasury bill rates partially undone through others. A tentative hypothesis is that more transparent regimes are less prone to this sort of pressure, but we cannot rely on evidence uncovered here to draw this conclusion.

Also somewhat speculatively, a belief that monetary policy may not matter may have played some role in the episode, as when the authorities may have attributed exchange rate weakening to capital account shocks at a time when policy rates were clearly negative. Clearly, in general shocks other than those to monetary policy are the main drivers of macroeconomic outcomes in countries such as those we examine here. But getting monetary policy broadly right may nonetheless be an important contributor to macroeconomic stability and thus eventually financial development and growth. Thus, we are reminded of another more recent Romer and Romer paper: "The Most Dangerous Idea in Federal Reserve History: Monetary Policy Does not Matter."47

The episode also illustrates the challenges posed to policy makers by supply shocks. While the standard policy recommendation calls for policy adjustments only to second round effects, disentangling them in a context of limited information might prove difficult. Going forward, these will likely continue to put pressure on policy frameworks around the world, and tools like the one presented in Andrle et al (2013) might be useful to calibrate the proper policy response.

Despite these results, much remains unknown about the transmission mechanism. The role of supply shocks, of food prices, of the banking system and limited financial participation, fiscal policy, limited capital account openness, and many other features deserve further exploration. And more complex situations than the events observed in late 2011 do not always admit to simple stories. The reduction of policy rates (in Kenya and Uganda) later in 2012 has not been followed by as clear a transmission to lending rates or real activity, for example. Major open policy questions remain. These include the management of capital account shocks and more broadly the place of sterilized intervention in the policy mix - a tool that seems as attractive to policymakers in this region as elsewhere.

Nonetheless, the results should be encouraging for the central banks considering moving towards forward-looking monetary policy frameworks such as inflation targeting. The transmission mechanism appears to be working, but it functions best when signals are clear and the regime simple and coherent. This also highlight the use of standard analytic tools such as small semi-structural inflation forecasting models for the formulation of policy, tools that can help countries avoid the go-stop policies such as those observed in 2011 and that can help support a clearer and hence more effective regime.

\footnotetext{
${ }^{47}$ Romer and Romer (2013).
} 


\section{REFERENCES}

Adam, C. (2012). Exchange Rate Policy. In E. Aryeetey, S. Devarajan, R. Kanbur, \& L. Kasekende (Eds.), The Oxford Companion to the Economics of Africa (pp. 352-358). Oxford: Oxford University Press.

Adam, C., Maturu, B., Ndung'u, N., \& O'Connell, S. (2010). Building a Monetary Regime for the 21 st Century. In C. Adam, P. Collier, \& N. Ndung'u (Eds.), Kenya: Policies for Prosperity. Oxford: Oxford University Press.

Adam, C., O'Connell, S., \& Buffie, E. (2009). Aid Volatility, Monetary Policy Rules and the Capital Account in African Economies. In G. Hammond, R. Kanbur, \& E. Prasad (Eds.), Monetary Policy Frameworks for Emerging Markets (pp. 95-114). London: Bank of England.

Allen, F. I. (Forthcoming). African Financial Systems: A Review. Review of Development Finance.

Andrle, M. A., Andrew Berg, Rogelio Morales, Rafael Portillo and Jan Vleck (2013). Forecasting and Monetary Policy Analysis in Low Income Countries (1): Food and Non-Food Inflation in Kenya. Working Paper, International Monetary Fund, Washington, D.C.

Andrle, M. A., Andrew Berg, Enrico Berkes, Rogelio Morales, Rafael Portillo, David Vavra and Jan Vleck (Forthcoming). Forecasting and Policy Analysis Systems in Low Icnome COuntries (2): The Role of Money Targeting in Kenya. Working Paper, International Monetary Fund, Washington, D.C.

Bank of Tanzania. (2011). The East African Community Governors' Meeting on the Current Economic Developments in the Region. Retrieved from http://www.bottz.org/Adverts/PressRelease/2011-Oct-13-PressRelease.pdf.

Bank of Tanzania. (2012). Monetary Policy Statement - The Mid Year Review. February.

Bank of Tanzania. (2012a). Monetary Policy Statement, June.

Bank of Uganda. (2011). Economic and Financial Indicators. February.

Bank of Uganda. (2011a). Economic and Financial Indicators. April

Bank of Uganda. (2011b). Monetary Policy Statement for October 2011. 
Berg, A., Portillo, R., \& Unsal, D. F. (2010). On the Optimal Adherence to Money Targets in a New-Keynesian Framework: An Application to Low-Income Countries. Working Paper, International Monetary Fund, Washington D.C.

Borio, C., \& Fritz, W. (1995). The Response of Short-Term Bank Lending Rates to Policy Rates: A Cross-Country Perspective. Working Paper, Bank for International Settlements.

Ceccetti, S. (1995). Distinguishing Theories of the Monetary Transmission Mechanism. Federal Reserve Bank of St. Louis Review. May/June.

Central Bank of Kenya. (2011). MPC Press Release. March.

Central Bank of Kenya. (2011a). MPC Press Release. July.

Central Bank of Kenya. (2011b). MPC Press Release. September.

Central Bank of Kenya. (2011c). MPC Press Release. October.

Central Bank of Kenya. (2011d). Seventh Biannual Report of the MPC. October.

Chinn, M., \& Ito, H. (2008). A New Measure of Financial Openness. Journal of Comparative Policy Analysis, 10(3), 309-322.

Christensen, B. (2011). Have Monetary Transmission Mechanisms in Africa Changed? Working Paper, Bank for International Settlements.

Cottarelli, C. and Kourelis, A. (1994). Financial Structure, Bank Lending Rates, and the Transmission Mechanis of Monetary Policy. Staff Papers - International Monetary Fund, 41(4), 587-623.

Cummins, J., Hassett, K., \& Hubbard, G. (1994). A Reconsideration of Investment Behaviour Using Tax Reforms as Natural Experiments. Brookings Papers on Economic Activity, 3(2).

Davoodi, H., Dixit, S., \& Pinter, G. (2013). Monetary Transmission Mechanism in the East African Community: An Empirical Investigation. Working Paper, International Monetary Fund, Washington, D.C.

Government of Rwanda. (2012). Enhancing Domestic Saving Mechanisms Towards SelfReliance. Retrieved February 2013, from Umushyikirano: www.umushyikirano.gov.rw/IMG/pdf/savings_mobilisation_mechanismndc_2012.pdf 
Huang, R. H., \& Shen, C.-H. (2001). The Monetary Policy Reaction Function for Taiwan: A Narrative Approach. Asian Economic Journal, 15(2), 199-215.

International Labor Organization. (2012). Studies on Growth with Equity: Kenya. Unpublished manuscript.

International Monetary Fund. (2008). Regional Economic Outlook: Sub-Saharan Africa. Washington D.C. April.

International Monetary Fund. (2011). Kenya-Staff Report for the 2011 Article IV Consultation, Second Review Under the Three-Year Arrangement Under the Extended Credit Facility and Requests for Modification of Performance Criteria and Augmentation of Access. Washington, D.C. November 23.

International Monetary Fund. (2011a). World Economic Outlook. Washington, D.C. April.

International Monetary Fund. (2011b). Regional Economic Outlook: Sub-Saharan Africa, Recovery and Risks . Washington, D.C. April.

International Monetary Fund. (2011c). Uganda-Second Review Under the Policy Support Instrument and Request for Waiver of Assessment Criteria. Washington, D.C. June 16.

International Monetary Fund. (2011d). Uganda-Third Review Under the Policy Support Instrument, Request for Waiver of Nonobservance of an Assessment Criterion, and Request for Modification of Assessment Criteria. Washington, D.C. December 21.

International Monetary Fund. (2011e). United Republic of Tanzania-Staff Report for the 2011 Article IV Consultation and Second Review Under the Policy Support Instrument. Washington, D.C. April 21.

International Monetary Fund. (2011f). United Republic of Tanzania-Third Review Under the Policy Support Instrument and Request for Waivers and Modification of Assessment Criteria. Washington, D.C. December 29.

International Monetary Fund. (2012). Kenya-Fourth Review Under the Three-Year Arrangement Under the Extended Credit Facility, Request for a Waiver and Modification of Performance Criteria - Staff Report. Country Report, Washington, D.C.

International Monetary Fund. (2012). Annual Report on Exchange Arrangements and Exchange Restrictions. Washington, D.C. Retrieved 2011, from http://www.imfareaer.org/Areaer/Pages/Home.aspx 
International Monetary Fund. (2013). United Republic of Tanzania-Sixth Review Under the Policy Support Instrument, Second Review Under the Standy Credit Facility Arrangement and Request for Modification of Performance Criteria - Staff Report. Washington, D.C. May 17.

Kasekende, L., \& Brownbridge, M. (2011). Post-Crisis Monetary Policy Frameworks in SubSaharan Africa. African Development Review, 23(2), 190-201.

Kessy, P. (2011). Dollarization in Tanzania: Empirical Evidence and Cross Country Experience. Working Paper, International Growth Center.

Kim, H. (1999). Was the Credit Channel a Key Monetary Transmission Mechanism Following the Recent Financial Crisis in the Republic of Korea? Working Paper, World Bank, Washington, D.C.

Laurens, B. (2005). Monetary Policy Implementation at Different Stages of Market Development. Occasional Paper, International Monetary Fund, Washington, D.C.

MacAuliffe, C., Saxena, S., \& Yabara, M. (2012). Sustaining Growth in the East African Community. In H. Davoodi (Ed.), The East African Community After Ten Years. Deepening Integration. Washington, D.C.: International Monetary Fund.

Masson, P., \& Pattillo, C. (2005). The Monetary Geography of Africa. Washington, D.C.: Brookings Institution Press.

Mishkin, F. (1996). The Channels of Monetary Transmission: Lessons for Monetary Policy. Working Paper, NBER.

Mishra, P., \& Montiel, P. (2012). How Effective is Monetary Transmission in Low Income Countries? A Survey of the Empirical Evidence. Working Paper, International Monetary Fund, Washington D.C.

Mishra, P., Montiel, P., \& Spilimbergo, A. (2012). Monetary Transmission in Low-Income Countries: Effectiveness and Policy Implications. IMF Economic Review(60), 270302.

Montiel, P., Adam, C., Mbowe, W., \& O’Connell, S. (2012). Financial Architecture and the Monetary Transmission Mechanism in Tanzania. Working Paper, International Growth Center.

Morales, R. (2012). Monetary Policy Harmonization in the East African Community. In H. Davoodi (Ed.), The East African Community After Ten Years. Deepening Integration. International Monetary Fund. 
Murinde, V. (2012). Banks and Credit Markets. In E. Aryeetey, S. Devarajan, R. Kanbur, \& L. Kasekende (Eds.), The Oxford Companion to the Economics of Africa (pp. 374379). Oxford: Oxford University Press.

Muse, M., Kiplang'at, S., \& Shimba, C. (2012). Segmentation and Efficiency of the Interbank Market in Kenya. Working Paper, Kenya Bankers Association, Center for Research on Financial Markets and Policy.

Murgosova, Z., Gorbanyov, M., Saenz, M. \& Sobolev, Y. (2008). Impact of Rising International Food and Fuel Price on Inflation in EAC Countries. Selected Issues Paper, International Monetary Fund, Washington D.C.

National Bank of Rwanda. (2011). Current Economic Developments and Monetary Policy Orientation.

National Bank of Rwanda. (2011a). The BNR Key Repo Rate Increased From 6\% to 6.5\%.

Nord, R., Sobolev, Y., Dunn, D., Hajdenberg, A., Hobdari, N., Maziad, S., \& Roudet, S. (2009). Tanzania: The Story of an African Transition. Washington, D.C.: International Monetary Fund.

O'Connell, S. (2012). Inflation Targeting in Africa. In E. Aryeetey, S. Devarajan, R. Kanbur, \& L. Kasekende (Eds.), The Oxford Companion to the Economics of Africa (pp. 360364). Oxford: Oxford University Press.

Romer, C., \& Romer, D. (1989). Does Monetary Policy Matter? A New Test in the Spirit of Friedman and Friedman. In NBER Macroecononomics Annual (Vol. 4, pp. 121-184). National Bureau of Economic Research.

Romer, C., \& Romer, D. (2010). The Macroeconomic Effects of Tax Changes: Estimates Based on a New Measure of Fiscal Shocks. American Economic Review, 100(3), 763 801.

Romer, C., \& Romer, D. (2013). The Most Dangerous Idea in Federal Reserve History: Monetary Policy Doesn't Matter. American Economic Review: Papers \& Proceedings, 100(3), 55-60.

Sanya, S., \& Gaertner, M. (2012). Assessing Bank Competition Within the East African Community. Working Paper, International Monetary Fund, Washington, D.C.

Saxegaard, M. (2006). Excess Liquidity and Efectiveness of Monetary Policy: Evidence from Sub-Saharan Africa. Working Paper, International Monetary Fund. 
Selassi, A. (2008). Beyond Macroeconomic Stability: The Quest for Industrialization in Uganda. Working Paper, International Monetary Fund, Washington, D.C.

Summers, L. (1991). The Scientific Illusion in Empirical Macroeconomics. Scandinavian Journal of Economics, 93(2), 129-148. 